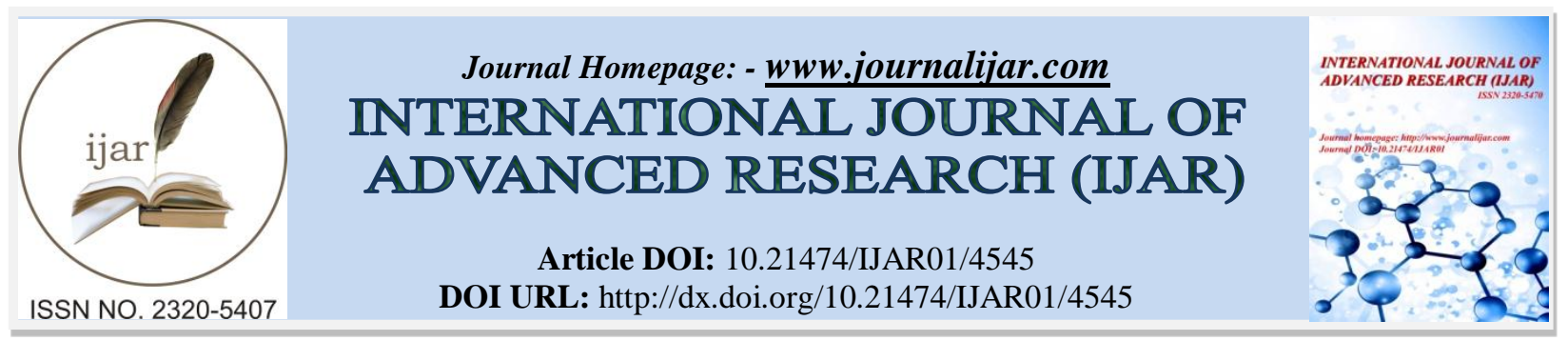

RESEARCH ARTICLE

\title{
SATIS GELISTIRME TEKNIKLERININ HAZCI (HEDONIK) TUKETIM UZERINDEKI ETKISI UZERINE BIR ARASTIRMA.
}

Yrd. Doc. Dr. Necla Kuduz and Prof. Dr. Semra Aytug.

1. Uşak Universitesi Uygulamalı Bilimler Yüksek Okulu.

2. Dokuz Eylül Üniversitesi İzmir Meslek Yüksek Okulu.

\section{Manuscript Info}

........................

Manuscript History

Received: 20 April 2017

Final Accepted: 22 May 2017

Published: June 2017

Key words:-

Marketing Communication, Sales

Promotion Activities, Hedonic

Consumption.

\section{Abstract}

With the various reasons such as globalization, technological developments, rapid population increase, changes occurring in the cultural and socioeconomic structure etc. Some changes occurred in the desires and needs, life styles and, hence, purchasing behaviors of consumers. On this point arrived, consumers not only make shopping to remove their needs, but also, besides this, they try to take delight from shopping.

Among the factors driving consumers to purchasing behavior, besides they need the goods and services, there is what these goods and services mean for them. This also revealed the concept of hedonic consumption.

Business enterprises, for being able to respond in time and correctly to the desires and needs of consumers, which rapidly change, searching for the various differentiation ways, have begun to develop the different sale and marketing methods. One of these is sale development among elements of marketing communication mix.

In this study, the effect of sales promotion activities, among elements of marketing communication mix, on hedonic consumption has been attempted to be examined.

* Bu çalışma, Dokuz Eylül Üniversitesi Sosyal Bilimler Enstitüsü İşletme Ana Bilim Dalı’nda tamamlanan "Satış Geliştirme Tekniklerinin Hazcı (Hedonik) Tüketim Üzerindeki Etkisi Üzerine Bir Araştırma" isimli doktora tezinin özeti niteliğinde hazırlanmıştır.

* Bu çalışma 18-19-20 Mayıs 2017 tarihlerinde Alanya Alaaddin Keykubat Üniversitesinde düzenlenmiş olan 2. Uluslararası Sosyal Bilimler Sempozyumu'na "Satış Geliştirme Tekniklerinin Hazcı (Hedonik) Tüketim Etkisi Üzerine Bir Araştırma" başlıklı özet bildiri ile sözlü olarak sunulmuştur.

\section{Giriş:-}

Hızla değişen piyasa şartları ve zorlu rekabet ortamının sonucu olarak pazarlama anlayışı da değişmektedir. Bu yoğun ve dinamik pazar ortamında işletmeler, 1900'lü yıllarda hâkim olan "ne üretirsem onu satarım" anlayışını terk etmiş, tüketici istek ve ihtiyaçlarına önem verilmeye başlanmış, tüketiciler pazarlama tekniklerinin odak noktası haline gelmiştir.Bilgi- iletişim teknolojisinde yaşanan hızlı gelişmeler, küreselleşme, sosyo-ekonomik ve kültürel değişmeler tüketicilerin yaşam tarzına yansıyarak, tüketici istek ve ihtiyaçlarını değiştirmiş, satın alma alışkanlıklarına yansımıştır.Teknolojik ilerlemeler sayesinde işletmelerin sunmuş olduğu mal ve hizmetler hemen 
hemen birbirine benzemeye başlamıştır. Küreselleşme ve bilişim teknolojilerinde yaşanan gelişmeler sonucunda ülkeler arası sınırlar ortadan kalkarak, çok fazla sayı ve çeşitte ürünle karşı karşıya kalınmıştır. Meydana gelen bu değişikliğin sonucu olarak işletmeler de sunmuş oldukları ürünlerde çeşitliliğe gidip, kaliteyi artırma yarışına girmişlerdir. Gelinen noktada kalitesi, sayısı ve çeşidi artan ürünler karşısında işletmeler zorlu bir rekabet ortamına girmiş, bunun sonucu olarak fiyatlar düşmüş aynı zamanda işletmeler satış ve pazarlama stratejilerini yeniden gözden geçirerek mal ve hizmet çeşitliliğine dayalı ürün farklılaştırması, fiyat farklılaştırmasına dayalı olarak fiyatlandırma stratejileri, satış geliştirme tekniklarını içeren tutundurma stratejileri geliştirmeye başlamışlardır.

Yaşanan tüm gelişmelerin sonucunda, en genel tanımı ile bireyin çeşitli nedenlerle oluşan ihtiyaçlarını gidermesi sonucu oluşan durum olarak tanımlanan tüketim kavramı da bu tanımdan uzaklaşmış ve farklı anlamlar kazanmıştır. Günümüzde alışveriş ve tüketim olgusu sadece ihtiyaçları karşılamaya yönelik bir kavram olmaktan çıkıp, yaşamın bir parçası haline gelmiş, duygusal anlamda haz duyabileceği ya da alışveriş esnasında zevk alabileceği bir durum haline gelmiştir. Tüketiciler artık geleneksel satın alma karar modellerinde bahsedilen rasyonel satın alma kararı yerine duygusal veya hissi boyutun öne çıktığı, keyif alma isteğinin arttığı satın alma kararları vermektedirler. Tüketiciler artık alışveriş yapma sürecinde gezmeyi, eğlenmeyi, dinlenmeyi ve güzel vakit geçirmeyi ve haz almayı istemektedir. Yaşanan tüm bu gelişmeler "hedonik tüketim" kavramını ortaya çıkarmıştır. Bu kavram özellikle 1980'li yıllardan sonra daha fazla inceleme konusu olmuştur. Bu konu ile ilgili en kapsamlı araştırmayı Arnold ve Raynolds (2003) yapmış ve "Hedonik Alışverişe Yönelten Nedenler" ölçeğini geliştirmişlerdir. Bunlar; Maceralçin Alışveriş, Sosyalleşmek İçin Alışveriş, Fikir Edinmek İçin Alışveriş, Rahatlamak İçin Alışveriş,Başkaları İçin Alışveriş ve Değer Elde Etmek İçin Alışveriş.Bu çalışmada esas konu olması bakımından "değer elde etmek için alışveriş" i kısaca açıklama gerekirse; bazı insanlar alışverişi kazanılacak bir oyun gibi göstermektedir. Bu tüketiciler, ucuzluk dönemlerini beklemek, indirimleri takip etmek, kelepir malları bulmak, ve pazarlık yapmakta büyük bir haz duymaktadır. Bu haz iki yönlüdür. İlki; bireyin en iyi ürünü en iyi fiyata alması nedeniyle kendisini akıllı bir tüketici olarak görmesinin vermiş olduğu haz, diğeri bazı insanların piyasa bilgileri ile kendilerinden gurur duyuyor olmasının verdiği haz.

Bu çalışmada; reklam, halkla ilişkiler, kişisel satış ve doğrudan pazarlama teknikleri dışında kalan, genellikle kısa süreli uygulanan, aracıları ve tüketicileri daha hızlı ve daha fazla satınalmaya teşvik edici tutundurma ve satış çabası olarak tanımlanmakta olan satış geliştirme tekniklerinin hedonik tüketim ile etkileşimi incelenmiştir.

\section{Satış Geliştirmenin Pazarlama İletişimi İçindeki Yeri ve Satış Geliştirme Teknikler:-}

Hızla gelişen ve gün geçtikçe küresel bir yapı kazanan ekonomik koşullarda, başarılı bir pazarlamayı amaçlayan işletme ve markaların, hedef kitlesine en kolay ve ekonomik yollardan ulaşabilmesinin unsurlarından bir tanesi olan satış geliştirme (Kara ve Duru, 2013:150); Terpstra ve Sarathy (2000: 490)'e göre; direkt olarak reklam, kişisel satış, halkla ilişkiler elemanları kapsamına girmeyen satış aktiviteleridir. Yi ve Yun (2009:29) satış geliştirmeyi "bir mal veya hizmetin alım veya satımını kısa vadede teşvik etmektir" şeklinde tanımlamışlardır. Kotler (2005:152) "A'dan Z'ye Pazarlama" adlı çalışmasında satış geliştirmeyi, "tüketicilerin ürünleri daha sonra değil de şimdi satın almalarını sağlayan teşvikler ve ödüller" şeklinde tanımlamaktadır.Satış Geliştirme Enstitüsü (ISP), satış geliştirmeyi, "son tüketiciyi belirli bir markayı satın alması için ikna etmek amacıyla, bir mal veya hizmete, genellikle geçici olarak değer katan pazarlamanın görünen parlak yüzeyidir" şeklinde tanımlanmaktadır (Aktaran: Baker,1993:436). Amerikan Pazarlama Birliği (AMA) satış geliştirmeyi, kişisel satış, reklam ve halkla ilişkiler/duyurum dışında kalan, tüketicileri satın almaya ve ürünü denemeye yönelten, aracıların etkinliğini arttıran, sınırlı bir dönemde toptancılar, perakendeciler ya da tüketiciler için yapılan, pazarlama baskısını arttırmaya yönelik uygulamalardır şeklinde tnımlamıştır (Aktaran: Engel ve diğerleri, 2000:422). Satış geliştirme tekniklerinin her biri birçok benzersiz niteliklere sahip olup; tüketicinin ilgisini çekerek ürünü satın almasını sağlar (Kotler ve Armstrong, 1993:396). Satış geliştirme teknikleri kısa dönemde satışları artırııı etkiye sahip iken; uzun dönemde marka sadakatinin yaratılmasında çok yararlı değildir. Tüketiciler satış geliştirme tekniklerinden etkilenebilir; ancak mağaza ve satış geliştirme tekniklerinin kendisine yararları hakkında bilgiye sahip olmaması halinde söz konusu faaliyetlere katılmayabilir (Levy ve Weitz,1995:422). Gedenk, pazarlama karması ile satış geliştirme arasındaki yakın ilişkiden ve ikisinin de aynı amaca yönelik olmasından yola çıkarak Tablo 1'de görüleceği gibi satış geliştirme pazarlama karması içinde değerlendirilmelidir görüşünü ileri sürmektedir (Aktaran: Gülçubuk, 2007:59). 
Tablo 1:- Satış Geliştirmenin Pazarlama Karması İçindeki Yeri.

\begin{tabular}{|c|c|}
\hline PAZARLAMA KARMASI & SATIŞ GELIŞTİRME TEKNIKKLERI \\
\hline Ürün Politikası & $\begin{array}{l}\text { - Satılan ürün ile birlikte verilen armağanlar, ürüne bandajlı başka ürünler, } \\
\text { aksiyonlara özel ambalajlar, çoklu ürün paketleri }\end{array}$ \\
\hline Fiyat Politikası & $\begin{array}{l}\text { - Satış geliştirme etkinliklerinde uygulanan özel fiyat indirimleri, } \\
\text { - Şok indirimli satışlar, miktar iskontoları, indirim kuponları, ödeme kolaylıkları }\end{array}$ \\
\hline Dağıtım Politikası & $\begin{array}{l}\text { - Satış noktalarında ürünün raflarında göze çarpıcı ve dikkat çekici şekilde yer } \\
\text { alması, değişik standtlar kullanılarak satış noktasında ikinci sergi alanı yaratma } \\
\text { ve ürününgörünürlüğünü artırma }\end{array}$ \\
\hline Tutundurma & $\begin{array}{l}\text { - Reklam harcamalarına katk1 } \\
\text { - Satış geliştirme kampanya ve aksiyonları sürecince bastırılan el ilanları/ gazete } \\
\text { ve dergi ilanları, ekleri ve insertler (duyurular) }\end{array}$ \\
\hline
\end{tabular}

Kaynak: Aktaran: Gülçubuk, 2007:59

Farklı şekillerde sınıflandırılabilen satış geliştirme teknikleri en genel haliyle; aracıya yönelik satış geliştirme, satış gücüne yönelik satış geliştirme ve tüketicilere yönelik satış geliştirme şeklinde 3 ana grupta toplanabilir. Aracılara yönelik satış geliştirme teknikleri, üreticiler ya da pazarlama kanalının diğer üyeleri tarafından ürünü dağıtım kanalından itme amacıyla kullanılmaktadır. (Clow ve Boock, 2002:307). Satış Gücüne Yönelik Satış Geliştirme Teknikleri'nin birinci amacı satış elemanlarının, işlerinde daha başarılı olmalarını sağlamak; ikinci amacı ise satış elemanlarının daha çok ve arzulu çalışmalarını sağlamaktır (Odabaşı ve Oyman, 2002:217). Tüketicilere Yönelik Satış Geliştirme Teknikleriise tüketicileri hemen o an satın almaya veya daha sonra satın almaya teşvik eden satış geliştirme teknikleridir. Günümüzde gelinen noktada tüketicilere doğrudan ve dolaylı olmak üzere uygulanan satış geliştirme teknikleri çeşitlidir. Şekil 1'de tüketicilere yönelik satış ve geliştirme teknikleri gösterilmiştir.

Şekil 1:- Tüketicilere Yönelik Satış Geliştirme Araçları

\begin{tabular}{|c|c|c|}
\hline & $\begin{array}{c}\text { Tüketicilere Yönelik Satış Geliştirme } \\
\text { Teknikleri }\end{array}$ & \\
\hline Fiyat Esaslı Teknikler & & Fiyat Dıșı Teknikler \\
\hline $\begin{array}{l}\text { - Satış Geliştirme Amaçlı, } \\
\text { - Satışı Teşvik Edici Fiyat } \\
\text { İndirimleri }\end{array}$ & & $\begin{array}{l}\text { Tüketicinin zihninde yer } \\
\text { edinebilme } \\
\text { (Ürünün Konumlandırılması) }\end{array}$ \\
\hline $\begin{array}{l}\text { - İndirimli Satışlar } \\
\text { - Özel Kampanya Fiyatları } \\
\text { (Hafta Sonu, Sezon Sonu Vb... }\end{array}$ & Ürün Esası Teknikler & $\begin{array}{c}\text { İletişim ve Görsel Destek İçeren } \\
\text { Teknikler }\end{array}$ \\
\hline $\begin{array}{l}\text { Özel Kampanya Fiyatları) } \\
\text { • İkramiye ve Teşvik Ödülü } \\
\text { (Gönder Çekilișe Katıl) }\end{array}$ & $\begin{array}{c}\text { Ürünün Çekiciliğini Öne Çıkarma, } \\
\text { Hatırlatma }\end{array}$ & Marka Bilinirliğini Artırma \\
\hline $\begin{array}{l}\text { - Kupon ve Bonuslar } \\
\text { - Aynı Fiyata Daha Çok Miktar } \\
\text { - Para İadesi } \\
\text { - Ürün Deneme Fiyatı } \\
\text { - Sadakat Primi } \\
\text { - Ödeme Kolaylığı } \\
\text { - Para Ödüllü Yarı̧malar } \\
\text { - Nakit Ödeme İskontoları } \\
\text { - Müşteri Kartlı Satın } \\
\text { Almalarda Özel İndirim } \\
\text { - Ödemeye Mahsuben Takas } \\
\text { Alma } \\
\text { (Eskiyi Getir Yeniyi Götür } \\
\text { Kampanyaları) } \\
\text { - İkramiye Pulu } \\
\text { - Dönemsel Puan Toplayıp }\end{array}$ & $\begin{array}{l}\text { - Örnek Ürün Dağıtımı } \\
\text { - Mağaza İçi Ürün Tanıtımı } \\
\text { - Ürün Özellikli Yarışmalar } \\
\text { - 1. Ürünü Alana 2. Ürün Bedava } \\
\text { - Aynı Markadan Hediye Paketi } \\
\text { - Farklı Markadan Hediye Paketi } \\
\text { - Eşantiyon ve Hediye Verme } \\
\text { - Çoklu Ürün Paketleri } \\
\text { - Büyük Hacimli Aksiyon Paketi } \\
\text { - Ürün Denettirme ve Tat Paneller }\end{array}$ & $\begin{array}{l}\text { - Promosyon Reklamları } \\
\text { - El ilanları } \\
\text { - Tavan Askı Sistemleri } \\
\text { - Promosyon Çerçeveleri } \\
\text { - POS ve POP Reklamları ve } \\
\text { Destek Malzeme } \\
\text { - Dön Kartlar, Reyon Giydirme } \\
\text { - Display ve Standlar } \\
\text { - 2. Satıs Noktası Oluşturma, } \\
\text { Palet ve Gondol Uygulamaları } \\
\text { - Kampanya Broşürleri } \\
\text { - Mağaza İçi Anons ve TV Yayını } \\
\text { - Merchandising Aktiviteleri } \\
\text { - Etkili Raf Düzenleme } \\
\text { - Fiyat Etiketleri }\end{array}$ \\
\hline
\end{tabular}


Kaynak: (Aktaran:Gülçubuk, 2007:70).

Satış Geliştirme Teknikleri ile İlgili Literatür Araştırması:-

Satış geliştirme teknikleri ile ilgili yapılan çalışmalardan bazıları şu şekildedir: Öztürk (1992) yapmış olduğu çalışmada tüketim malları üreten işletmelerde tüketicilere yönelik satış geliştirme tekniklerini ve planlama sürecini incelemiştir. Wansink (1996) yaptığı çalışmada satış geliş̧irme teknikleri ve birim maliyetler göz önünde tutularak ürünlerin ambalaj boyutlarının ürün tüketimi üzerine etkisini araştırmıştır. Yolal (1998) yapmış olduğu alan araştırmasında; konaklama işletmelerinde ön büronun satış geliştirme ve gelir artırmadaki işlevinin yapısal analizini yapmıştır. Chen ve diğerleri (1998) yaptıkları çalışmada satış geliştirme tekniklerinden fiyat indirimleri ve kupon uygulamalarını inceleyerek bu uygulamaların ürünlerin yüksek ya da düşük fiyatlı olmalarına bağlı olarak oransal veya rakamsal olarak duyurumunun tüketicilerin algılarını ne yönde etkilediğini araştırmışlardır. Tyagi (1999) yapmış olduğu çalışmada perakendecilerin talep şartları doğrultusunda üreticilerin sunmuş oldukları satış geliştirme tekniklerini ne oranda tüketicilere yansıttıklarını incelemiştir. Gedenk ve Neslin (1999) satış geliştirme tekniklerinin tüketicilerin gelecekte yapacakları satın almaları ne şekilde etkileyeceğini, bu tekniklerinin satış artı̧̧ı üzerindeki etkilerini ve tüketicide bir marka sadakati yaratıp yaratmayacağını incelemişlerdir. Ailawadi (2001) yaptığ 1 çalışmada perakendecilere yönelik uygulanan satış geliştirme tekniklerininüreticilere de en az perakendeciler kadar katkı sağladığını ve üreticilerin satış geliştirme tekniklerine harcadıkları bütçelerin artmasına rağmen kârlılıklarının perakendecilere göre azalmadığını ifade etmiştir. Dikici (2001) yapmış olduğu çalışmada Isparta'da faaliyet gösteren süper marketlerin satış geliştirme tekniklerini incelemiştir. Srinavasan ve diğerleri (2002) çalışmalarında, satış geliştirme tekniklerinin uygulanmasının perakendeciye ya da üreticiye ek kazanç imkanı sağlayıp sağlamadıklarını, bu imkanın sağlandığ araştırmışlardır. Sethuraman ve Tellis (2002) yaptıkları çalışmada üreticilerin yapmış oldukları reklam uygulamalarının perakendecilerin uygulamış oldukları satış geliştirme teknikleri üzerinde ne şekilde etkisi olduğunu incelemişlerdir. Hardesty ve Bearden (2003) yapmış oldukları çalışmada fiyat indirimine yönelik satı̧̧ geliştirme teknikleri ve avantajlı paketlerin tüketici algısında yarattıkları fayda seviyelerini araştırmışlardır. Bridges ve diğerleri (2006) yaptıkları çalışmada tüketicilerin satış geliştirme tekniklerine bağlı olarak vermiş oldukları tepkilerin, daha önceden yapmış oldukları satın alımlarla ne şekilde bağlantılı olduğu araştırmışlardır. Koldaş (2006) yapmış olduğu çalışmada ticari fuarların satış geliştirme etkisini incelemiştir. Gürcan (2007) yaptığı çalışmada Denizli tekstil sektöründe sponsorluk yönetiminin tutundurma etkisini araştırmıştır. Akdoğan (2007) yaptığ 1 çalışmada endüstriyel pazarlarda aracılara uygulanan satış geliştirme tekniklerinin satışla ilişkisini araştırmıştır. Sigue (2008) yaptı̆̆ çalışmada üreticiler ya da perakendeciler kontrolünde tüketicilere yönelik uygulanan satış geliştirme tekniklerinin üreticilerin ve perakendecilerin kararları ve kârlılık üzerindeki etkilerini incelemiştir. Ülker (2009) yaptığ çalışmada yeni ürünlerde uygulanan tutundurma stratejilerini incelemiştir. Akın (2009) yaptığ1 çalı̧̧mada kooperatif işletmelerinde tutundurma tekniklerinin etkinliği açısından bütünleşik pazarlama iletişimini incelemiştir.

\section{Haz ve Hazcılık (Hedonizm) Kavramı, Tanımı, Çeşitleri, Özellikleri ve Hazcı (Hedonik) Tüketim:-}

Bireylerin biyolojik, psikolojik ve sosyal açıdan yaşamlarını devam ettirebilmeleri için gereksinimlerini karşılayabilmeleri gerekmektedir. Haz insanın dünyaya gözlerini açışından itibaren varolan doğal bir eğilimdir ve insan olmak için kendisine haz verecek eğilimlere ve nesnelere yönelir. Haz kavramı birçok filozofun ilgi alanına girmiş, haz ile ilgili farklı bazı noktaları ele alarak benzer fikirler ileri sürmüşlerdir (Özdemir, 2007: 70).Longman Dictionary of Contemporary English hazzı "yaşanılan deneyimlerden hoşlanma, mutluluk hissi duyma ya da tatmin olma" olarak tanımlamıştır (ldoceonline, 2014). Yaygın olarak kabul edilen görüşlerden biri mutluluğun haz olduğudur (White, 2006: 41) ve bir hedonist sadece hazzı maximuma çıkarmaya ve acıyı minimuma indirmeye çalışır (Kizza, 2010:35). Sokrates öğrencilerine mutluluğun iyiliğe yönelmek ve onu gerçekleştirmekle elde edilebileceğini öğretmiştir. Sokrates'in öğrencisi olan Kirene'li Aristippos, iyiliğin ne olduğu konusundaki arayışlara cevap olarak en üstün iyiliğin haz olduğunu ileri sürerek hazcılık kavramını geliştirmiştir (Hançerlioğlu, 2004:153; Flocker, 2004: 22-23). Aristotales' e göre zevk, insanın doğasında vardır.İnsana en çok tatmin sağlayan zevk, kazanılmış ya da gerçekleştirilmiş güçlerin etkin bir şekilde kullanılmasıyla sağlanır. Zevk, etkinlikleri geliştirererek hayatı mükemmelleştirir, zevk ve hayat birbirine bağlıdır (Fromm, 1995:202).

Hazzın mutlak anlamda iyi olduğunu, insan eylemlerinin nihai anlamda haz sağlayacak bir biçimde planlanması gerektiğini, sürekli haz verene yönelmenin en uygun davranış biçimi olduğunu savunan felsefi görüş olan hazcılık veya hedonizm; Kirene Okulu'nun, yani Sokrates'in öğrencisi Aristippos'un (M.Ö. 435-355) öğretisidir. En iyinin zevk olduğu öğreti, zevkin takibi, zevk aramaya adanmış hayat tarzı olarak tanımlanan hedonizm ile büyü yaratılmakta veya dünyaya sihir bağışlanmaktadır. Hedonik deneyim; zevk, fantezi, hisler,canlandırma ve eğlence 
ile bağdaştırılmaktadır (Hopkinson ve Pujari, 1994:274). İlk olarak felsefi açıdan ele alınmış ve incelenmiş olan hedonizm veya diğer adıyla hazcılık, felsefi bir terim olarak yaşamın amacı için hazzı seçen felsefe sistemini veya hazza aşırı düşkünlüğü anlatmaktadır. Haz almayı yaşamın amacı olarak görmekte ve sürekli olarak metalardan edinilebilecek hazları ön plana çıkarmaktadır. Bu durum var olma ya da ihtiyaçları karşılamak için değil, haz almak için tüketmek anlamına gelmektedir (Baudrillard, 2004:94).Etzioni'ye göre hedonizm, bir toplumun kuralc1 değerlerinin değer kaybetmesi ve yerine yeni kurallar konmadan kaybolması sonucunda gelişmiştir (Aktaran: Carman, 1978:403-407).

Hedonizmin kurucusu Epikur, insanların mutluluğu için hazlardan ölçülü bir şekilde yararlanmayı, yani doğal ve zorunlu hazlara bağlanmayı, doğal ve zorunlu olmayanlardan da kaçınmayı önermektedir. Epikur, yalnızca doğru hazzın bilgece, ölçülü, öngörü sahibi ve sürekli ve dingin bir doyum uğruna şu andaki hazzını yadsımaya hazır olan kişiler tarafindan elde edilebileceğini savunmuştur (Fromm, 1991:172). Hint kültüründeki Nirvana felsefesinin özü ise "istırapların kaynağını ihtiyaçlar olarak açıklar ve dolayısıyla ihtiyacı ortadan kaldırdığınız zaman ıstırap da son bulur" şeklindedir (Karabulut, 1987:9).Aristippos'a göre "iyi” oldukça şiddetli anlık hazdır. Bu hazzı elde edebilmek için bilgiye gereksinim vardır bu açıdan bakıldığında mutluluğa sadece bilgi aracılığıyla ulaşılabilir. Gelecekteki güzel duygusu henüz ortaya çıkmamış; geçmiş de ortadan kalkmış bitmiştir o halde biricik yaşama bilgeliği yaşanılanandan tat almaktır. Bireye ait olan şu andır ve hiçbir zaman sahip olunamayacak şeyler için üzülmenin anlamı yoktur. Bu açıdan Aristippos hazzı şimdiki ana bağlayarak maddesel haz ve acılara ruhsal haz ve acılardan daha fazla değer vermektedir. Hiçbir eğlenceyi kaçırmayan aynı zamanda her an kendine ve davranışlarına hâkim olabilen insan yaşamdan en çok kazanır. Gelecekten kaygılanmamalı ve geçmiş için pişman olunmamalı, insan içinde bulunduğu anı yaşamalı hiçbir durumda neşesini kaybetmemelidir (Akarsu, 1998:57-64).

\section{Hazcılığın (Hedonizmin) Çeşitleri, Yapısı ve Özellikleri:-}

Geleneksel olarak, iki tür hedonizmden söz edilebilir; felsefi ve psikolojik hedonizm. Felsefi hedonizme göre hazzın en yükseğe getirilmesi her bireyin ulaşmak istediği bir amaçtır ve birey bunun için çaba harcar. İkinci tür hedonizm olan psikolojik hedonizm ise güdülenme ile açılanmaya çalışılır. Hedonizmin bu türünde insan, doğası gereği zevk aldığı ya da haz duyduğu şeylere ulaşmak ister, arzularına göre hareket etmeye meyillidir ve bu arzularına ulaşmak için çaba harcar (Fromm, 1991:19-20). Penpece (2006:89) hedonizmi geleneksel ve modern olmak üzere iki şekilde ele almıştır. Modern hedonizmi gelenekselden ayıran temel fark, modern tüketicinin daha fazla "heyecan merkezli" davranması şeklinde açıklanmaktadır. Penpece, tüketicilerin dişil ve eril davranışlarını ele aldığı alan araştırmasında "alışverişi sevme, yakışan ürünleri tercih etme, öğrenme merakı, farklı hissetme" gibi boyutları dişil olanların daha yüksek derecede hissettiğini ifade etmektedir. Bu açıklamalar ışı̆̆ında, hedonizm ile tüketim arasındaki bağlantıyı incelemek kolaylaşmaktadır. Modern tüketimin hedonist (hazc1) yapısı, romantik dönemin başlangıcı olan 18. yüzyı1 Batı Avrupa'sına ve özellikle de İngiltere'ye dayanmaktadır. Tüketim ve tüketiciyi inceleyen bilim dalları ve bu konudaki araştırmalar, modern tüketicinin sadece akılcı ve ekonomik bir tüketim davranışı göstermediğini açıklamaktadır. Tüketici, romantik duyguların ve güdülerin etkisinde kalarak da tüketim deneyimini gerçekleştirmektedir (Holbrook,1996: 26).Romantizm ve duygusallığın satın alma davranışındaki yeri ve etkisini inceleyen Holbrook; romantizmin tüketicilerin yaşamları üzerindeki etkisini açıklayan modelin yetersiz kaldığını savunmaktadır. Bu açıdan bakıldığında hedonizm, deneyimin haz boyutundan zevk almak şeklinde tanımlanabilir. Temel amaç; yaşam boyu gerçekleşen deneyimlerden, duyular aracilığıyla elde edilebilecek haz kalitesini olabildiğince elde edebilmektir. Hedonist yaklaşım, duyguların da ötesine geçerek hazzın kaynağının tüketim deneyimindeki duyuların rolüne önem vermektedir. Temel ilginin, tüketimden duyular aracılığıyla elde edilecek hazzın, duygular ve düşler aracılığıyla elde edilmesine geçmesinin nedeni çağdaş hedonizmin gelişmesi olmuştur. $\mathrm{Bu}$ yüzden hazcı tüketim, malların ve hizmetlerin duygusal önemlerinden elde edilen tatmin olarak düşünülebilir (Odabaşı, 2006: 113).

Hazcı (Hedonik) İhtiyaçlar, Hazcı (Hedonik) Tüketim Kavramı ve (Hazcı) Hedonik Tüketim Davranışı:İnsanlar yaşamlarını devam ettirmek için gerekli olan belirli elementlerin (hava, su, yiyecek, barınma gibi) gereksinimiyle doğarlar; ancak insanın doğuştan olmayan başka gereksinimleri de vardır. Belirli bir kültürün üyesi olma, güç, statü ve bağlı olma gibi gereksinimler yanında hazcı (hedonik) gereksinimler de vardır. Hazcı (hedonik) gereksinimler kişisel ve deneyimseldir; tüketici bir ürünü, heyecan, kendine güveni ya da fantezi gereksinimi karşılamak için, dünyevi ya da sıradan yaşam bakış açısından kaçmak için satın alabilir. Tüketiciler birçok fayda sağladığı için de bir ürünü satın almaya motive olabilirler. Örneğin; bir vizon palto tanımladığı lüks imaj yüzünden satın alınabildiği gibi soğuk kışa rağmen sıcak tuttuğu için de satın alınabilir (Solomon, 2006: 123). 
Yaşanan çeşitli toplumsal ve teknolojik gelişmelerin sonucu olarak tüketim olgusu, öncesinden farklı olarak yalnızca ihtiyaçların değil arzuların tatminine de yönelmiştir (Odabaşı, 2006: 40). Tüketiciler her gün pek çok satınalma kararı vermektedir. Araştırmacılar; tüketicilerin ne aldıklarını, nereden aldıklarını, ne kadara aldıklarını ortaya çıkarmak için analiz yapmaktadır. Ancak; tüketicilerin satın alma davranışı nedenlerini öğrenmek kolay değildir. Bunun cevabı tüketicinin zihninde derinlerde kilitlidir ve tüketicinin kara kutusu olarak adlandırılır (Kotler ve Armstrong, 2008: 130-131). Rosinsky (2004:5)'e göre tüketiciler istek ve ihtiyaç duydukları şeyler için para harcar. Hedonik tüketim terimi 1982'de Hirschman ve Holbrook tarafindan yayınlanan makaleye dayanmaktadır. Yazarlar; hedonik tüketim görüşünü deneysel olarak geliştirmişlerdir (Hiraoka, 2009: 30).Modern tüketim toplumlarında tüketim olgusunun sahip olduğu anlam, fiziksel ihtiyaçları tatmin etmekten ziyade duygusal içeriklerle açılanmaya başlanmıştır. Bu bağlamda üreticiler, tüm pazarlama tekniklerinde, ürünün jenerik değerinden çok sağladığı hazzı ya da duygusal anlamlarını öne çıkarmaya başlamıştır. Terminolojik olarak hedonik tüketim, tüketimin çoklu duyuşsal (multi-sensory), fantezi ve duygular ile ilgili olan davranış boyutlarıdır (Hirscman ve Holbrook, 1982: 45).

Tüketici davranışının önemli bir alanı olan hedonik tüketim; tüketici davranışlarının ürün kullanımının duygusal, fantezi ve duygulandırıcı yönleri ile ilgili boyutu şseklinde tanımlanabilir. Tüketiciler sadece en iyi olanı değil, ayrıca onları en çok mutlu eden şeyi de seçmektedir. Tüketici tercihleri; tüketim sonunda hedonik deneyimin artmasını amaçlayan stratejiye göre belirlenir. Hedonik tüketim teorik olarak estetik, dil bilimi, psikoloji, psikoloji dili, sosyoloji gibi birkaç davranış biliminin içinde açıklanır (Kop, 2008: 88-89). Hedonik tüketim kavramından ilk olarak Colin Campell 1987 yılında yayınladığı "Modern Tüketimciliğin Ruhu ve Romantik Etik" kitabında bahsetmiştir. 18. yüzyılda insanların aşk romanlarından etkilenerek, romantik duyguların ve güdüleyicilerin etkisi altında kalarak tüketime yöneldiklerinden bahsetmiştir (Campell, 1987: 19-45). Genellikle alışveriş motivasyonları faydacı ve hedonik olmak üzere iki anahtar bakış açısıyla kategorize edilmektedir (Nguyen ve Barret, 2006: 230). Hedonik tüketici estetik, denyimsel ve kârla ilgili zevkler peşinde koşarken; faydacı tüketici görevsel, rasyonel, fonksiyonel, yararlı ve pratik kârlar peşinde koşmaktadır (Pöyry, 2012: 1797). Hirschman ve Holbrook yayınladıkları "Hedonik Tüketim: Ortaya çıkan Kavramlar, Yöntemler ve Öneriler" adlı makalelerinde hedonik tüketimin, kişinin ürünlerle ilgili deneyiminin heyecanlandırıcı yönlerini, fantezi ve çoklu duyusal ile ilişkili olan tüketici davranışları görünümünü belirttiğini ifade etmişlerdir yani hedonik tüketim tüketicilerin ürünün kullanımında duygusal tahrik, fantezi ve çoklu duyusal düşlerini işaret etmektedir (1982: 92-97). Bir başka tanımda ise hedonik tüketim;tüketici davranışının bireyin ürün tecrübesinin çoklu duyuşsal, fantezi ve duygu unsurları ile ilgili yönlerini tanımlar şeklindedir (Halbrook, 1982: 92; Elizabeth C. Hirschman ve Morris B: 101).

1994'te Babin, Darden ve Griffin “İş ya da Eğlence: Hedonik ve Faydacı Alışveriş Değerinin Ölçülmesi” adlı makalelerinde alışverişin hazcı ve faydacı değer yönü üzerinde durmuş, hazcılık ve faydacılık arasındaki temel farka değinmişlerdir. Hazcı alışveriş değeri tahrik olma, fantezilerin yerine getirilmesi, yüksek katılım, algılanan özgürlük ve kaçışı içermekteve alışveriş satınalma ile ya da satınalma olmaksızın sonuçlansa da hedonik değer sağlayabileceğini ileri sürmüşlerdir (Babin ve Griffin, 1994: 646). O’Shaughnessy çalışmasında küreselleşme, pazarlama, tüketim toplumu ve hedonistik yaşam tarzı arasındaki ilişkiyi incelemiştir (O'Shaughnessy, 2002: 77). Okado (2005: 44)'e göre hedonik tüketim, "tüketicilerin üründen algıladıkları imaj, fantezi ve duygusal uyarımlara dayanan tüketim biçimidir".Hedonik tüketimin, alışverişte belirli ürünleri elde etme isteğinden öte, bazı tüketici etkinliklerine neden olduğu ve satın alma güdüsünün hazza dayalı olması durumunda tüketicilerin daha yüksek ilgi durumlarının gözlendiği savunulmaktadır. (Zaichkowsky,1985: 341-352). Günümüzde hedonik (hazc1) tüketim, pazarlama, pazarlama iletişimi ve tüketici davranışlarının önemli bir alanı olmuştur (Hopkinson ve Pujari,1999: 274). Spangenberg, Voss ve Crowley (1997: 239) hedonik tüketimi "tüketimin duygusal boyutuyla ilgilenen ve duygusal hazzı tamamlamaya, yaşatmaya odaklanan tüketim biçimidir" şeklinde tanımlamışlardır.Hedonik tüketim görüşüne göre, ürünler nesnel varlıklar olarak değil de daha çok öznel semboller olarak tanımlanır. Ürünün ne olduğundan çok neyi temsil ettiği önemlidir ve odak noktası gerçek değil de ürünün taşıdığı ve yarattığ imajdır. Anahtar ölçüt ise, anlamın öğrenilmesinden ziyade tüketicinin duygusal tepkisidir (Odabaş1, 2006: 116).Hedonik tüketimin temel güdüleri içsel ya da dişsal olabildiği gibi bireysel ya da toplumsal da olabilmektedir. Hedonik tüketimin bireysel nedenleri olarak; fiziksel aktiviteler, eğlenceler, mal ya da hizmeti ucuza alabilme isteği, duyusal uyarılar, sıkıntı duyma ve kişisel haz elde etme isteği gibi nedenler sayılmaktadır. Hedonik tüketimin toplumsal nedenleri arasında ise toplumsal deneyim kazanma, iletişim kurma, toplumun ileri gelen kişilerinden etkilenme, referans grupları ve görüşme gibi nedenler sayılmaktadır (Antonides ve Raaij, 1998: 420).

Hedonizmin belki de en önemli yönü alışveriş yapmadaki beklentilerdir. Bilindiği gibi alışveriş ve satın alma eylemlerinden beklentiler faydacı beklentiler ve hedonik beklentiler gibi iki ana başlığa ayrılmaktadır. Faydacı beklentilerde tüketici, ürünün işlevsel, nesnel özelliklerine ağırlık verirken; hedonik beklentilerde duygusal tepkiler, 
duygusal hazlar, düş kurma ve estetik beklentiler ön plandadır. Yüksek arzular, genişletilmiş ilgilenimler, fanteziler ve gerçeğin tatsızlığından kaçışlar gibi faktörlerin hepsi hedonik alışveriş deneyiminin belirtileridir. Bu açıdan bakıldığında, hedonik beklentiler öznel olduğu kadar semboliktirler (Babin, Darden ve Griffin, 1994: 646; Khan, Urminsky, 2004: 1). Hedonik tüketim kavramının teorik altyapısının oluşturulmasında davranış bilimlerinden; kültür üretim sistemi ile Becker 1973, Hirsch 1972; felsefe içerisinde estetik; psikoloji içerisinde fantezi imaj, günlük düşler çalışmaları ile Singer 1966, Swanson 1978 gibi farklı uzmanlaşmış alt alanlardan yararlanılmıştır. Levy 1959, 1964; Hirchman ve Holbrook 1981, 1982 yıllarındaki çalışmalarında sembolik tüketimin hedonik deneyimle olan ilişkisi ele alınmıştır. Hirschman ve Holbrook hedonik tüketimin, ürün deneyiminin heyecanlandırıcı, fantezi ve çoklu duyusal yönlerine ilişkin tüketici davranışları görünümünü gösterdiğini belirtmiştir (Hirschman ve Holbrook, 1982: 92-93).

Alışverişte hedonik ve faydacı beklentiler, tek boyutlu bir ölçeğin iki ucu olarak düşünülmemelidir. Yapılan araştırmalar, tüketici algılarının ve tercihlerinin hem hedonik hem de faydacı beklentileri içerdiğini göstermektedir (Dhar ve Wertenbroch, 2000: 60). Tüketiciler çoğu ürünün tüketiminde her iki tip fayda beklentisine girmekle birlikte, bazı ürünleri hedonik, bazılarını ise daha fazla faydacı alışveriş olarak tanımlamaktadırlar (Westbrook ve Black, 1985: 78-103). Hedonik alışverişler üzerine dikkatlerin çekilmesinde, farklı konularda yapılan çalışmalardan elde edilen sonuçların da etkisi olmuştur. Feick ve Price (1987) makalelerinde "Pazar Kurtları"ndan bahsetmiş, diğer insanları belirli alışverişlerde en iyi fiyatı elde etmeleri için bilgilendiren bir tüketici dilimi şeklinde tanımlamışlardır. Slama ve Williams (1990) ise "Pazar Kurtları" ölçeğini geliştirmek amacı ile bir çalışma yapmış; araştırma sonucunda ise, bu bireylerin, sadece daha çok bilgi arayışı ve diğerlerini bilgilendirme amaçlı hareket etmediklerini, alışveriş yapmaktan daha çok zevk alan bireyler olduklarını belirlemişlerdir (Akca, 2009: 47-48). Hedonik tüketim üzerine yapılan çalışmalar aşağıdaki gibi gösterilebilir.

Tablo 2:- Hedonik Tüketim Üzerine Yazılmış Önemli Çalışmalar.

\begin{tabular}{|c|c|c|}
\hline YAZARLAR & & KATKILAR \\
\hline $\begin{array}{l}\text { Holbrook } \\
\text { Hirchmann(1982) }\end{array}$ & ve & $\begin{array}{l}\text { Hedonik tüketimi, tüketici davranışının ürün kullanım deneyiminin çoklu hissiyat, fantezi } \\
\text { ve duygusal bakış açılarına bağlayan yüzeyleri olarak tanımlamaktadır. Dört boyut ele } \\
\text { alınmıştır: zihinsel yapı, ürün sınıfları, ürün kullanımı, bireysel farklılıklar. }\end{array}$ \\
\hline $\begin{array}{l}\text { Batra } \\
\text { Ahtola(1990) }\end{array}$ & ve & $\begin{array}{l}\text { Tüketicilerin ürün ve hizmetleri satın alıp, tüketim davranışını ilk temel nedenle } \\
\text { gerçekleştirdiklerinden, tüketici tutumları iki boyutlu olarak önerilmektedir. Hissi } \\
\text { özellikler ve hissi olmayan faydacı özellikler }\end{array}$ \\
\hline Sheth(1991) & & $\begin{array}{l}\text { Tüketici tercih davranışını etkileyen beş ürün fayda kategorisi belirlemiştir: Fonksiyonel, } \\
\text { sosyal, Duygusal, Epistemic ve kondisyonel. }\end{array}$ \\
\hline $\begin{array}{l}\text { Spangenberg, } \\
\text { Crowley } \\
\text { Hughes }(1991)\end{array}$ & ve & Ürün kategorilerinin hedonik ve faydacı boyutlara göre haritalanması. \\
\hline $\begin{array}{l}\text { Babin, Darden } \\
\text { Griffin } \\
\text { (1994) }\end{array}$ & ve & $\begin{array}{l}\text { Hedonik ve faydacı değerler ile ilgili literatür araştırması ve bu değerlerin birbirleriyle } \\
\text { olan ilişkilerinin teorik tanımları ardından hedonik ve faydacı değerlerin ölçümü için } \\
\text { ölçek geliştirilmiştir. }\end{array}$ \\
\hline Lia(1995) & & Tüketicilerin ürün değerlendirmesine yönelik çerçeve ve fayda tipolojisi. \\
\hline $\begin{array}{l}\text { Spangenbery } \\
\text { Voss(1997) }\end{array}$ & ve & Geniş anlamda kullanılabilecek HED/UT Ölçeğinin geliştirilmesi \\
\hline $\begin{array}{l}\text { Brown } \\
\text { Venkatesh(2001) }\end{array}$ & ve & $\begin{array}{l}\text { Amerikan evlerindeki PC adaptasyonunu etkileyen faktörler için yapılan ulusal, iki } \\
\text { dalgalı, boyuna bir araştırmanın sonuçlarını sunmaktadır. Bulgular, benimseme ve } \\
\text { benimsememeyi yöneten kararların önemi ölçüde farklı olduğunu ortaya koymaktadır. }\end{array}$ \\
\hline $\begin{array}{l}\text { Spangenbery } \\
\text { Voss(2003) }\end{array}$ & ve & $\begin{array}{l}\text { Markaya karş1 tutumun tek boyutlu ölçümü olan merkezi rota işleme modeline (Central } \\
\text { Route Processing Model) alternative olan hedonik/ faydacı tutum boyutlarını içeren } \\
\text { merkezi rota işleme modeli. }\end{array}$ \\
\hline $\begin{array}{l}\text { Inman } \\
\text { Wakefield(2003) }\end{array}$ & ve & $\begin{array}{l}\text { Hane halkı gelirinin fiyat hassasiyetine olan etkisinin duruma göre değişken olduğu } \\
\text { savunulmaktadır. Bireylerin, fonksiyonel ya da hedonik tüketim durumlarında ürün } \\
\text { alırken eşit düzeyde fiyata hassas olup olmadıkları ve sosyal yapının fiyat hassasiyetini } \\
\text { etkileyip etkilemediği irdelenmiştir }\end{array}$ \\
\hline $\begin{array}{l}\text { Labarge } \\
\text { Dacin }(2004)\end{array}$ & ve & $\begin{array}{l}\text { Alışkanlığa dayalı, risk taşımayan hazcı aktivitelerin sebeplerini üç genel kategoride } \\
\text { toplamaktadır. }\end{array}$ \\
\hline Heijden(2004) & & rimlilik odaklı (faydacı) ve keyif odaklı (hedonik) bilişim sistemleri için kullanıcı kabul \\
\hline
\end{tabular}


modelleri arasındaki farklılıkları çalışmaktadır.

Tüketimin Karar verme kavramına bağlı olarak hazcı faydacı tüketime karşı tipik satın alma durumlarında nasıl değiştiğini araştırmaktadır.

Kaynak: Çoruh, 2011: 39.

\section{Hazcı (Hedonik) Alışverişin Nedenleri:-}

Hedonik beklentiler daha çok, fanteziler, eğlence, tensel zevkler, sembolik değerler ve statü arayışı odaklı olurken;faydacı beklentiler fonksiyonel ihtiyaçlara odaklanmaktadır. Benzer bir sınıflandırma alışverişe gitmenin nedenleri açısından da yapılabilir (Solomon, 1983: 314). Alş̧verişte hedonik ve yararcı beklentiler, tek boyutlu bir ölçeğin iki ucu olarak düşünülmemelidir. Yapılan araştırmalar, tüketici algılarının ve tercihlerinin hem hedonik hem de yararcı beklentileri içerdiğini (Ravi Dhar ve Klaus Wertenbroch, 2000: 60); hedonik alışverişin çeşitli beklentilerden yola çıkılarak yapıldığını dolayısıyla tüketicilerin sadece haz almak için hareket etmediklerini ve haz arayışına farklı nedenlerle yöneldiklerini göstermiştir. Bu konuyla ilgili en kapsamlı araştırmayı Arnold ve Reynolds yaparak "Hedonik Alışverişe Yönelten Nedenler" ölçeğini geliştirmişlerdir. Yazarlara göre hedonik alışverişin nedenleri su şekildedir (Arnold ve Reynolds,2003: 77-95) :Macera İçin Alışveriş; uyarılma, macera ve farklı bir dünyada olma duygusu gibi anlamları içinde barındıran alışverişleri içermektedir. Pek çok tüketici, alışverişe tamamen bir heyecan ya da macera için gittiğini ifade etmektedir. Bu tip alışveriş yapan tüketiciler, alışveriş merkezine gittiklerinde kendilerini akıntıya kapılmış gibi hissettiklerini, zamanın nasıl geçtiğinin farkında olmadıklarını ifade etmektedirler.Sosyalleşmek İ̧̧in Alışveriş; arkadaş ve aile ile alışverişten hoşlanma, onlarla bir arada bulunma, sosyalleşme ya da alışveriş yaparken diğer insanlarla bağlantı kurmayı ifade etmektedir. Sosyalleşmek için alı̧veriş yapan tüketiciler, arkadaş ve aile ile alışverişe gitmenin, onlarla vakit geçirmenin bir yolu olduğunu ifade etmektedirler.Rahatlamak İ̧̧in Alışverişs;stresten kurtulmak, olumsuz ruh halini azaltmak ve bir tür özel terapi gibi anlamları içinde barındıran alışveriştir. Bazı tüketiciler, günlük hayatın verdiği stresten kurtulmak, kafasını başka şeylerle meşgul etmek, rahatlamak amacıyla alışverişe çıkmaktadır.Fikir Edinmek Için Alışveriş; yeni ürün ve gelişmelerden haberdar olmak, yeni trend ve modaları takip etmek için yapılan alışverişlerdir. Belirli bir satınalma ihtiyacı ya da kararı olmaksızın sadece bilgi toplama amacıyla yapılan bu alışverişte, kişiler alışverişi bir tür eğlence ya da boş vakit değerlendirme yolu olarak kullanmaktadır.Başsalarını Mutlu Etmek İ̧̧in Alışveriş; kişilerin bir başkası için alışveriş yaparken yaşadıkları keyfi ve olumlu düşünceleri içermektedir. Birçok insan sevdiği, değer verdiği insanlar için alışveriş yaptıkları zamanlarda, kendilerini mutlu hissetmektedir. Bu yönüyle bazı kişiler açısından, aileleri ve arkadaşları için alışveriş yapmak çok önemli olmakta ve bu alışveriş kişilerin kendilerini daha iyi hissetmelerini sağlayabilmektedir. Bazı zamanlarda, sevilen bir insan için mükemmel hediyeyi bulmak büyük bir haz sağlayabilmektedir. Bu duygu özellikle kadınların satın alma davranışlarında görülmektedir. Tamamı olmasa da kadın tüketicilerin bazıları alışverişi, sevgilerini ya da aşklarını ifade etmenin bir yolu olarak gördüklerini ifade etmişlerdir.Değer Elde Etmek İçin Alışveriş; daha çok indirimleri takip etme, pazarlık yapma gibi anlamlarıyla önem kazanmaktadır. Bu sınıfta yer alan tüketiciler, indirimleri takip etmek, ucuzluk dönemlerini beklemek ve kelepir malları bulmak amacıyla alışveriş yapmakta ve bu alışverişten büyük bir haz duymaktadır. Bu haz iki yönlü olabilmektedir. İlki; kişinin en iyi ürünü, en uygun fiyatla alması nedeniyle kendini akıllı bir tüketici olarak görmenin vermiş olduğu hazdır. İkincici; bazı insanlar piyasa bilgileri ile kendilerinden gurur duyarlar. En güzel ve ucuz ürünün nerede olduğunu, fiyatının ne olduğunu etrafındaki kişilere aktarmak oldukça haz verici bir doyum sağlayabilmektedir.

\section{Satış Geliştirme Teknikleri İle Hedonik Tüketim Arasındaki İlişki:-}

İşletmelerin satışlarını artırmak için kullanmış oldukları satış geliştirme teknikleri, satışları artırmanın yanında tüketicilere de bu satış geliştirme teknikleri sayesinde mal ve hizmetleri daha ucuzasatın alma imkanı sağlamakta, aynı fiyata bir ürün yerine birden fazla ürün alabilme ve özel günlerde hediye kazanma şansı yakalama imkanı sağlamaktadır. Bunlara ek olarak satış geliştirme teknikleri, tüketiciler için haz verici bir uygulama çeşitidir. Örneğin; yarışma ve çekilişlerde, tüketiciler zevkli ve heyecanlı anlar yaşamaktadır. Ayrıca, satış geliştirme teknikleri planlı olmayan satın almaları artırabildiği için, satış ve mağaza trafiğinin artmasını sağlayabilmektedir. Satış geliştirme tekniklerini planlayan ve uygulayanların yaratıcılıklarına paralel olarak; sınırsız şekilde yapılabilmesi mümkündür (Odabaşı ve Oyman, 2002: 197). Tüm bunların yanında işletmelerin uygulamış olduğu satış geliştirme teknikleri hedonik tüketiciler üzerinde de etkili olmaktadır. Hedonik tüketimin nedenlerinden biri olan değer elde etmek için alışveriş yapan tüketicilerin satın alma kararları satış geliştirme tekniklerinden etkilenmektedir. Yapılan çalışmalar dolaylı da olsa bu sonucu vermektedir.

Hedonik tüketim üzerine dikkatlerin çekilmesinde, farklı konularda yapılan çalışmalardan elde edilen sonuçların da etkisi olmuştur. Feick ve Price (1987) makalelerinde "Pazar Kurtları"ndan bahsetmiş, "diğer insanları belirli 
alışverişlerde en iyi fiyatı elde etmeleri için bilgilendiren bir tüketici dilimi” şeklinde tanımlamışlardır. Slama ve Williams (1990) ise "Pazar Kurtları" ölçeğini geliştirmek amacı ile bir çalışma yapmış; araştırma sonucunda ise, bu bireylerin, sadece daha çok bilgi arayışı ve diğerlerini bilgilendirme amaçlı hareket etmediklerini, alışveriş yapmaktan daha çok zevk alan bireyler olduklarını belirlemişlerdir (Akca, 2009: 47-48). Anlık satın almalarda, tüketici bir ürüne gereksinimi olmamasına rağmen satın alma gereksinimi duyabilir. Tüketiciler hedonik değere pazarlık algılayışıyla da ulaşabilir. Fiyat kalite literatürü; değeri, ürünün iş görme fonksiyonunun faydası ve ürün satış fiyatı ile bir tüketicinin iç referans fiyatı arasındaki farklılık olarak tanımlamıştır. Bu bağlamda; bir tüketici bit pazarına gider ve şunu vurgular; birçok insanla birlikte burada olmak çok heyecanlı bir duygu, gerçekten bir pazarlık yapacağınızı biliyorsunuz ve ucuza alacaksınız (Babin ve Griffin, 1994: 646). Chen ve diğerleri (1998) yaptıkları çalışmada satış geliştirme tekniklerinden fìyat indirimleri ve kupon uygulamalarını inceleyerek bu uygulamaların ürünlerin yüksek ya da düşük fiyatlı olmalarına bağlı olarak oransal veya rakamsal olarak duyurumunun tüketicilerin algılarını ne yönde etkilediğini araştırmışlardır. Hardesty ve Bearden (2003) yapmış oldukları çalışmada fiyat indirimine yönelik satış geliştirme teknikleri ve avantajlı paketlerin tüketici algısında yarattıkları fayda seviyelerini araştırmışlardır. Bridges ve diğerleri (2006) yaptıkları çalışmada tüketicilerin satış geliştirme tekniklerine bağlı olarak vermiş oldukları tepkilerin, daha önceden yapmış oldukları satın alımlarla ne şekilde bağlantılı olduğu araştırmışlardır. Penpece (2006: 89) hedonizmi geleneksel ve modern olmak üzere iki şekilde ele almış; modern hedonizmi gelenekselden ayıran temel fark1 ise, modern tüketicinin daha fazla "heyecan merkezli" davranması şeklinde açıklamıştır. Yanıklar (2006: 103); "tüketim, özellikle de ihtiyaçları karşılamanın ötesinde yapılan tüketim, tüketicilere haz sağlamaktadır" şeklinde ifade etmiştir. Ülker (2009) yaptığı çalışmada yeni ürünlerde uygulanan tutundurma stratejilerini incelemiş̧ir. Bir gazete; fiyat indirimlerini eroin gibi alışması kolay, bırakması zor bir alışkanlık olarak nitelemiştir (Slater, 2001: 3-7). Kuponlar ve kısa dönemli fiyat indirimleri satış geliştirmenin en yaygın formu olduğu için, çoğu araştırma satış geliştirmenin tüketiciye tek yararını parasal tasarruflar olarak görmektedir; ancak satış geliştirme, parasal tasarrufların ötesinde tüketiciye hedonik ve işlevsel yararlar sunabilir. Hedonik yararlar, eğlence ve heyecan unsurlarını içerirken; işlevsel-faydacı yararlar ise bilişsel, işlevsel, ekonomiklik, kalite, uygunluk gibi yararlar içerir. Parasal olmayan teşvikler daha çok hedonik yarar sağlarken; daha az işlevsel yarar sağlar. Parasal teşvikler faydacı ürünlerde hedonik ürünlerden daha etkilidir (Chandon, 2000: 77).

Alışverişte hedonik ve faydacı beklentiler, tek boyutlu bir ölçeğin iki ucu olarak düşünülmemelidir. Yapılan araştırmalar, tüketici algılarının ve tercihlerinin hem hedonik hem de faydacı beklentileri içerdiğini göstermektedir (Dhar ve Wertenbroch,2000: 60). Tüketiciler çoğu ürünün tüketiminde her iki tip fayda beklentisine girmekle birlikte, bazı ürünleri hedonik, bazılarını ise daha fazla faydacı alışveriş olarak tanımlamaktadır (Westbrook ve Black, 1985: 78-103). Tüm bulguların ışığında denilebilir ki satış geliştirme teknikleri hedonik tüketim davranışlarını etkilemektedir.

\section{Satış Geliştirme Tekniklerinin Hazcı (Hedonik) Tüketim Üzerindeki Etkisi Üzerine Bir Araştırma: Konya Örneği:-}

Çalışmanın bu bölümünde Konya ilinde yaşayan tüketicilerin alışveriş yapma alışkanlıklarında satış geliştirme tekniklerinin etkisinin olup olmadığı; satış geliştirme tekniklerinin hedonik tüketim üzerinde etkisinin olup olmadığı, etkiliyorsa ne yönde etkilediğini belirlemek amacıyla yapılan araştırmanın sonuçlarına yer verilecek ve elde edilen bulgular tartışlacaktır.

\section{Araştırmanın Konusu, Amacı ve Önemi:-}

En genel tanımı ile bireyin çeşitli nedenlerle oluşan ihtiyaçlarını gidermesi sonucu oluşan durum olarak tanımlanan tüketim kavramı bu tanımdan uzaklaşmış ve farklı anlamlar kazanmıştır. Günümüzde alışveriş ve tüketim olgusu sadece ihtiyaçları karşılamaya yönelik bir kavram olmaktan çıkıp; yaşamın bir parçası haline gelerek, duygusal anlamda haz duyabileceği ya da alışveriş esnasında zevk alabileceği bir durum haline gelmiştir. Tüketiciler artık geleneksel satın alma karar modellerinde bahsedilen rasyonel satın alma kararı yerine duygusal veya hissi boyutun öne çıktığ 1 , keyif alma isteğinin arttığı satın alma kararları vermektedir. Günümüzde tüketiciler alışveriş yapma sürecinde gezmeyi, eğlenmeyi, dinlenmeyi ve güzel vakit geçirmeyi ve haz almayı istemektedir. Yaşanan tüm bu gelişmeler "hedonik tüketim” kavramını ortaya çıkarmıştır. Bu kavram özellikle 1980'li yıllardan sonra daha fazla inceleme konusu olmuştur. Bu konu ile ilgili en kapsamlı araştırma Arnold ve Raynolds (2003) tarafından yapılmış ve "Hedonik Alışverişe Yönelten Nedenler" ölçeğini geliştirmişlerdir. Bunlar; Maceracı Alışveriş, Rahatlamak İçin Alışveriş, Fikir Edinmek İçin Akılveriş, Sosyal Amaçlı Alışveriş, Başkaları İçin Alışveriş ve Değer Elde Etmek İçin Alışveriştir. Bu çalışmada esas konu olması bakımından "değer elde etmek için alışveriş"i kısaca açıklama gerekirse; bazı insanlar alışverişi kazanılacak bir oyun gibi görmektedir. Bu tüketiciler, ucuzluk dönemlerini beklemek, indirimleri takip etmek, kelepir malları bulmak, ve pazarlık yapmakta büyük bir haz duymaktadır. Bu haz 
iki yönlü olup; ilki bireyin en iyi ürünü en iyi fiyata alması nedeniyle kendisini akıllı bir tüketici olarak görmesinin vermiş olduğu haz, diğeri bazı insanların piyasa bilgileri ile kendilerinden gurur duyuyor olmasının verdiği hazdır .Bu çalışmada; reklam, halkla ilişkiler, kişisel satış ve doğrudan pazarlama teknikleri dışında kalan, genellikle kısa süreli uygulanan, aracıları ve tüketicileri daha hızlı ve daha fazla satın almaya teşvik edici tutundurma ve satış tekniği olarak tanımlanmakta olan satış geliştirme tekniklerinin hedonik tüketim ile etkileşimi incelenmiştir. Bu araştırmanın esas amacı Konya'da bulunan alışveriş merkezlerinin uygulamış olduğu satı̧ geliştirme tekniklerinin hedonik tüketicilerin satın alma davranışları üzerinde etkili olup olmadığının belirlenmesidir. Araştırmada esas olarak tanımlayıcı araştırma modeli kullanılmıştır. Bu bağlamda araştırmanın alt amaçlarını şu şekilde sıralamak mümkündür:

* Tüketicilerin satış geliştirme tekniklerine bakış açısını ölçmek,

* Tüketicilerin işletmelerin uygulamış oluğu satış geliştirme tekniklerinden etkilenip etkilenmeme derecesini ölçmek,

* Tüketicilerin satış geliştirme tekniklerinden duyduğu hazzı ölçmek

* İşletmelerin uygulayacakları satış geliştirme tekniklerine katkıda bulunmak.

İşletmelerin uygulamış olduğu satış geliştirme tekniklerinin tüketicilerin satınalma davranışlarına etkisini belirlemeye yönelik olarak yapılan bu araştırma ile yurt içinde ve yurt dışında yapılan araştırmaların sonuçları karşılaştırılmış olacaktır. Satı̧̧ Geliştirme Teknikleri ile ilgili literatür incelendiğinde Türkiye'de satış geliştirme teknikleri konulu çalışmaların sınırlı sayıda olduğu görülmektedir. Aynı şekilde hedonik tüketim konulu çalışmaların sayısı da sınrlıdır. Özellikle satış geliştirme tekniklerinin hedonik tüketim üzerindeki etkisini ölçen bir çalışma hemen hemen yok sayılır. Dolayısıyla, bu araştırmanın en önemli özelliği literatüre yapacağı katkıdır. Araştırma sonucu elde edilen veriler, ileride bu konuda yapılacak diğer araştırmalara da temel oluşturabilir ve Türkiye'deki işletmelere satış geliştirme teknikleri ile ilgili stratejilerini belirlerken dikkat etmeleri gereken noktalar konusunda faydalı olabilir. Aynı zamanda hedonik tüketicilerle ilgili aydınlatıcı bilgiler sunabilir.

\section{Araştırmanın Kapsamı:-}

Araştırmanın kapsamı, araştırma süresince yapılan literatür taramalarından elde edilen bulgular ışı̆̆ında, tüketicilerin satış geliştirme teknikleri hakkındaki tutum ve davranışlarını ölçmek amacıyla Konya ilinde yaşayan ve büyük alışveriş merkezlerinden mal ve hizmet satın alan tüketiciler olarak belirlenmiştir. Bu bağlamda gerekli verileri elde etmek için düzenlenmiş olan anket formu Konya ilinde yaşayan, büyük alışveriş merkezlerinden mal ve hizmet satın alan 527 tüketici üzerinde uygulanmış olup; herhangi bir ürün kısıtlamasına gidilmemiş genel alışveriş alışveriş alışkanlıkları üzerinde durulmuştur.

\section{Araştırmanın Sınırlılıkları (Kısıtları):-}

$\mathrm{Bu}$ araştırmanın en önemli kısıtlarından bir tanesi, daha önce çalışma yapanların da belirttiği üzere satış geliştirme tekniklerinin hedonik tüketim üzerindeki etkisini ölçen çalışma sayısının az olmasıdır. Ayrıca hedonik tüketim alanında yapılmış olan pek çok çalışmaya ulaşılamamıştır. Bir diğer önemli kısıt da tüketicilerin hedonik tüketim alı̧̧kanlıklarına yönelik sorulara -sosyal kabul görmek için- yanlı cevap vermeleri yani olanı değil de olması gerekeni yansıtmaya yatkın olmalarıdır. Bazı tüketicilerin ankete katılmak istememesi de önemli bir kısıttır.Araştırma sadece Konya il sınırları içinde yaşayan tüketiciler üzerinde uygulanmıştır. Dolayısıyla sonuçların Türkiye'nin diğer şehirlerinde yaşamakta olan tüketicileri de temsil edecek şekilde Türkiye geneli için yorumlanması doğru değildir. Aynı şekilde araştırma sadece Konya il sınırları içerisinde bulunan alışveriş merkezlerinde uygulanmış olduğundan diğer sektörlerde farklı sonuçlar verebilir. Diğer taraftan her çalışmada olduğu gibi zaman ve maliyet kısıtları söz konusudur.

\section{Araştırmanın Yöntemi:-}

Çalışmanın bu bölümünde araştırmanın dayandığı model ve hipotezler, anket sorularının hazırlanması, test edilmesi ve anket formunun oluşturulması, ana kitle ve örnek kitlenin seçimi ve veri toplama yöntemi hakkında bilgilere yer verilecektir.

\section{Araştırmanın Modeli ve Hipotezleri:- Araştırmanın Modeli:-}

Bu araştırmada, araştırmanın amaçlarına uygun olarak "Tanımlayıcı (Betimsel) Araştırma Modeli” kullanılmıştır. Tanımlayıcı araştırmanın esas amacı; eldeki problemi, bu problemle ilgili durumları, değişkenleri, bu değişkenler arasındaki ilişkileri tanımlamaktır. Tanımlayııı araştırma modelinde iki veya daha fazla değişken arasındaki ilişkinin 
derecesi belirlenebilmektedir (Kurtuluş, 2004: 252). Tanımlayıcı araştırma modelleri genellikle şu durumlarda kullanılır:

* Belirli grupların özelliklerini tanımlamak. Örneğin, bir markanın kullanıcısı konumundaki tüketicilerin demografik özelliklerini saptamak.

* Belirli bir davranış sergileyen tüketici kitlesinin toplam tüketici sayısı içindeki oranını hesaplamak. Örneğin, bir yerleşim yerinde yeni açılan süpermarketlerden alışveriş yapanların oranını hesaplamak.

* Geleceğe dönük tahminler ışığında çeşitli stratejiler geliştirmek. Örneğin, gelecekte pazarın genişleyeceği veya yeni pazarlara girileceği tahmin edildiğinde, satışgücünün büyüklüğünü bugünden saptamak veya satışçların eğitimi konusunda çalışmalar yapmak.

Araştırmada kullanılan araştırma modeli aşağıda Şekil 2'de gösterilmiştir.

Şekil 2:- Araştırmanın Modeli

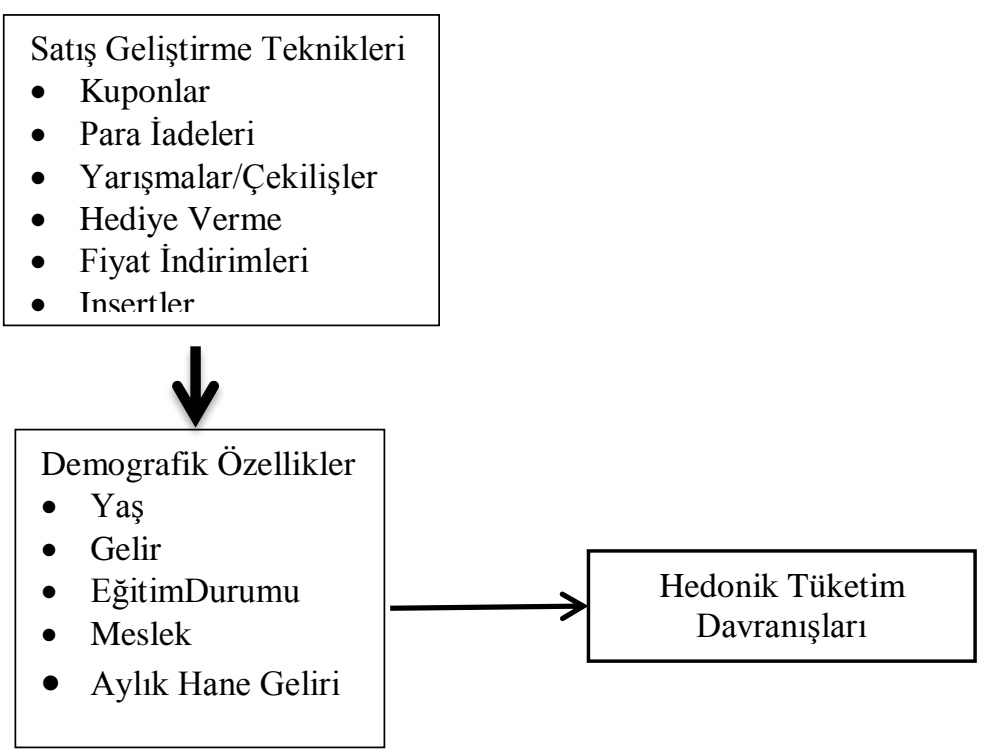

Araştırmanın Hipotezleri:-

Hipotez, araştırmacının araştırma problemindeki değişkenler arasındaki ilişkilerinden beklentilerini ifade eder. Null (sıfır) hipotezleri genellikle fark olmadığ 1 tezi üzerine kurulmaktadır. Geleneksel şekilde Null Hipotezi $\mathrm{H}_{0}$ olarak sembolize edilmektedir. Her Null hipotezine karşıllık mutlaka bir alternatif hipotez vardır. Alternatif hipotez $\mathrm{H}_{1}$ olarak sembolize edilmektedir (Altunışık, 2004: 20,60). Hipotez testi ise, örneklem değerlerini kullanarak hipotezin doğruluğunu saptama işlemidir. Hipotez testleri, genellikle iki şekilde yapılır (Aktaran: Yükselen, 2003: 29):

* Örnekten alınan gözlem değerlerinin, ana kitle (evren) için varsayılan bir değerden farkının anlamlı olup olmadığg testi.

* İki veya daha fazla sayıda örnekten alınan gözlem değerleri arasındaki farkın anlamlı olup olmadığı testi.

* Araştırmanın amacı ve modeli doğrultusunda uygulamayla ilgili geliştirilen hipotezleri şu şekilde göstermek mümkündür:

H1: Araştırmaya katılan tüketiciler hedonik tüketim davranışı göstermektedir.

H1a: Araştırmaya katılan tüketicilerin alışverişten zevk alma düzeyi yüksektir.

H1b: Araştırmaya katılan tüketicilerin promosyonlu ürünleri tercih etme düzeyi yüksektir.

H2: Satış geliş̧tirme teknikleri ile hedonik tüketim davranışları arasında anlamlı bir iliş̧i bulunmaktadır.

H2a: Bir ürünü satın alırken öncelikle fiyatına dikkat eden tüketicilerin, satın alma kararlarında işletmelerin yapmış olduğu fiyat indirimlerinden etkilenmeleri arasında ilişki bulunmaktadır.

H2b: Promosyonlu ürünleri tercih eden tüketicilerin, promosyonlar sayesinde yeni ürünleri denemeleri arasında iliş̧i bulunmaktadır.

H2c: Promosyonlu ürünleri tercih eden tüketicilerin, promosyonlar sayesinde kendini iyi hissetmeleri arasında ilişki bulunmaktadir.

H2d: Promosyonları takip ettiği için çevresindeki insanların kendisini takdir ettiğini düşünen tüketicilerin, promosyonlu ürünleri tercih etmeleri arasında ilişki bulunmaktadır. 
H2e: Promosyonlu ürünleri tercih eden tüketicilerin, promosyonları takip ettiği için çevresindeki insanların kendisini takdir ettiğini düşünmeleri arasında ilişki bulunmaktadır.

H2f: Promosyonlu ürünleri tercih eden tüketicilerin, ihtiyacı olmasa bile bir ürünü promosyon olduğu için satın almaları arasında ilişki bulunmaktadır.

$\mathrm{H} 2 \mathrm{~g}$ : Promosyonlu ürünleri tercih eden tüketicilerin, aklındaki marka yerine promosyonlu markayı tercih etmeleri arasında ilişki bulunmaktadır.

\section{Anket Formunun Oluşturulması ve Veri Toplama Yöntemi:-}

Araştırmada veri toplama metodu olarak anket yöntemi kullanılmıştır. Anket formunun oluşturulmasında yerli ve yabancı literatür taraması yapılarak daha önce yapılan anket çalışmaları incelenmiştir. Sorular konuyla ilgili araştırmalar neticesinde araştırmacı ve tez danışmanı tarafından geliştirilmiştir. Diğer araştırmalarda yer alan soruların bir kısmı olduğu gibi alınmış; bir kısmı içinde bulunulan zaman, anakitlenin özellikleri ve araştırmanın amac1 gibi özellikler göz bulundurularak yeniden şekillendirilmiștir. Anket formu 5'li likert ölçeği kullanılarak hazırlanmıştır. Ölçek adını geliştirici olan Rennis Likert’ten almış olup; Likert Ölçeği olarak anılmaktadır. Bu ölçekte katılımcıya çeşitli ifadeler ve yargılar yöneltilir ve katılımcıdan bu ifadelere katılıp katılmama derecesini belirtmesi istenir. Kategori sayısına bağlı olarak; 5,7,9 ve 11'li olabilen bu ölçek, yaygın olarak 5'li Likert Ölçeği tercih edilmektedir. Likert ölçeğinde cevaplar katılıp katılmama ile ilgilidir. Likert ölçeğinde yer alan ifadeler ayrı ayrı değerlendirilebilir. İfadeler arası korelasyon ya da ilişki incelenebilir (Altunışık ve diğerleri,2010: 115116).Tüketicilerin alışveriş tutum/davranışlarını ölçmeye yarayan yedinci bölümde yer alan 1. soru ve 2. soru (Akça; 2009)'un araştırmasından uyarlanarak ankete adapte edilmiştir. 3. soru ve 4. soru (Kop; 2008)' in araştırmasından uyarlanarak ankete adapte edilmiştir.Tüketicilerin alışveriş tutum/davranışlarını ölçmeye yarayan sekizinci bölümde yer alan 1. ve 2. Sorular (Kop;2008)'in araştırmasından uyarlanarak ankete adapte edilmiştir. 3. soru (Ünal ve Ceylan; 2008)'in araştırmasından uyarkanarak ankete adapte edişmiştir. 4. soru (Kop; 2008)'in araştırmasından uyarlanarak ankete adapte edilmiştir. 5. soru ve 6. soru (Ünal ve Ceylan; 2008)'ın araştırmasından uyarlanarak ankete adapte edilmiştir. 7. soru ve 8.soru (Özdemir ve Yaman, 2007 )'ın araştırmasından uyarlanarak ankete adapte edilmiştir. 9. soru (Ebrahimi, 2013)' nin araştırmasından uyarlanarak ankete adapte edilmiştir. 10.soru (Kop, 2008)' in araştırmasından uyarlanarak ankete adapte edilmiştir. 11. soru (Aydın, 2009)'ın araştırmasından uyarlanarak ankete adapte edilmiştir. 12. soru ve 13. soru (Kop; 2008) un aşatırmasından uyarlanarak ankete adapte edilmiştir. 14. soru, 15. soru, 16. soru ve 17. soru (Kop, 2008)' un araştırmasından uyarlanarak ankete adapte edilmiştir. 18. soru ve 19. Soru (Özdemir ve Yaman; 2007)' in araştırmasından uyarlanarak ankete adapte edilmiştir. 20. soru (Ünal ve Ceylan; 2008)'ın araştırmasından uyarlanarak ankete adapte edilmiştir. 21. ve 22. soru (Penpeçe; 2006)'nin araştırmasından uyarlanarak ankete adapte edilmiştir. 23. soru ve 24. soru (Kop; 2008)'in araştırmasından uyarlanarak ankete adapte edilmiştir. 25. soru (Penpeçe; 2006)'nin araştırmasından uyarlanarak ankete alınmıştır.

Satış geliştirme tekniklerinin hedonik tüketim üzerindeki etkisini ölçmeye yarayan dokuzuncu bölümde yer alan 1 . soru, 2. soru ve 3. soru (Kara ve Duru; 2013)'nun araştırmasından uyarlanarak ankete adapte edilmiştir. 4. soru, 5. soru ve 6. Soru (Bulut; 2007)'un araştırmasından uyarlanarak ankete adapte edilmiştir. 7. soru (Kara ve Duru; 2013)'nun araştırmasından uyarlanarak ankete adapte edilmiştir. 8. soru (Bulut; 2007)'un araştırmasından uyarlanarak ankete adapte edilmiştir. 10. soru, 11. soru. 12. soru, 13. soru, 14. soru ve 15. soru (Kara ve Duru, 2013)'nun araştırmasından uyarlanarak ankete adapte edilmiştir.Anket sorularının yeterince açık ve anlaşılır nitelikte olup olmadığını anlamak üzere anket formuna son şeklini vermeden önce Konya il sınırları içerisinde bulunan alışveriş merkezlerinden alışveriş yapan 50 denek üzerinde test edilerek pilot çalışma yapılmıştır. Bu sayı örneklemin \%10'unu teşkil etmektedir. Pilot çalışma sonrasında gerekli düzeltmeler yapıldıktan sonra anketin yazı stili ve şekil özellikleri belirlenmiştir. Tüketicilerin mesleklerini öğrenmeye yönelik olan soru hem çoktan seçmeli hem de açık uçlu soru türündedir.Anketin ikinci bölümünde, araştırmaya katılan tüketicilerin hedonik tüketim davranışlarını ölçmeye yönelik sorular sorulmuştur.Anketin üçüncü ve son bölümünde ise; araştırmaya katılan tüketicilerin satı̧̧ geliştirme tekniklerini ölçmeye yönelik sorular sorulmuştur.

\section{Anakitle ve Örnek Kitlenin Seçimi:-}

$\mathrm{Bu}$ araştırmada anakitle Konya ili merkezde yaşayan tüm tüketicilerdir. Araştırmanın amacı satış geliştirme tekniklerinin hedonik tüketicilerin satınalma davranışlarına etkisini ölçmek olduğundan araştırmanın amacına uygun ana kitlenin özelliklerini taşıyan örneklere ulaşabilmek için yargısal örnekleme yöntemi izlenmiş ve Konya ili merkezde yaşayan ve büyük alı̧sveriş merkezlerinden mal ve hizmet satın alan tüketiciler üzerinde yapılmıştır. Yargısal örnekleme yönteminde araştırmacı örnek birimlerini kendi kararına göre seçmekte; örnek büyüklüğün yeterli olup olmadığına veri toplama süreci içerisinde karar vermektedir (Yükselen, 2004: 59). Alışveriş 
merkezlerinin seçilmesinin nedeni pek çok farklı fiyatta ve çeşitte mal ve hizmeti bir arada bulundurma imkânı olması, pek çok farklı sosyo-ekonomik düzeyde tüketicinin bir arada bulunması gibi avantajlarından dolayıdır. Anakitleden seçilecek gerekli örneklem büyüklüğünün belirlenmesinde örneklem büyüklüğünü belirmeden kullanılan şu formül kullanılmıştır (Kurtuluş, 2004: 191): $n=p \cdot(1-p) /(e / Z)^{2} \mathrm{Bu}$ formüldeki sembollerin anlamları şöyledir: $n=$ örnek hacmi, $p$ : incelenen olayın görüş sıklığı, $\mathbf{e}=$ hata payı oranı, $z=$ güven aralığı. Çalışma $\% 95$ güven aralığında (Z), \%5 hata payı (e) ile anketi cevaplayacak kişilerin \%50 olasılıkla (p) doğru ya da yanlış cevap verecekleri göz önünde bulundurularak belirlenen 527 alışveriş merkezi tüketicisi üzerinde gerçekleştirilmiştir.Verilerin elde edilmesinde yüz yüze anket yöntemi kullanılmıştır. Anket formları 01 Nisan 2015 - 12 Mayıs 2015 tarihleri arasında Konya'da bulunan beş büyük alışveriş merkezinde uygulanmıştır. Anketlerin uygulanmasında 5 anketör kullanılmış olup; anketörler anketleri alışveriş merkezinden mal ve hizmet satın almış olan tüketiciler üzerinde uygulamışlardır. Bir anketin tamamlanma süresi ortalama 15 dakikadır.

\section{Güvenilirlik Analizi ve Sonuçları:-}

Yapılan her ölçüm için gerekli olan güvenirlilik, bir ankette yer alan soruların birbirleriyle olan tutarlllığı ve kullanılan ölçeğin ilgilenen soruyu ne kadar yansıttığını göstermektedir. Güvenilirlik, elde edilen ölçümler üzerinde yorumlar ve analizler için bir temel teşkil etmektedir (Kalayc1, 2006: 403). Bireylerin verdikleri cevaplar arasındaki tutarlılı̆̆ 1 şeklinde tanımlanan güvenirlilik, testin ölçülmek isteneni ne derece doğru ölçtüğünü göstermektedir (Büyüköztürk, 2003: 163). Cronbach's Alpha katsayısına bağlı olarak ölçeğin güvenirliliği aşağıdaki gibi yorumlanmaktadır (Kalayc1, 2006: 405):

$0.00 \leq \alpha<0.40$ olduğu durumda ölçek güvenilir değil,

$0.40 \leq \alpha<0.60$ olduğu durumda ölçek güvenirliliği düşük,

$0.60 \leq \alpha<0.80$ olduğu durumda ölçek güvenirliliği oldukça yüksek,

$0.80 \leq \alpha<1.00$ olduğu durumda ölçek yüksek derecede güvenilir.

Yapılan güvenirlilik analizi sonucunda, güvenirlilik katsayısı (Cronbach's Alpha) ölçekteki 25 sorudan oluşan tüketicilerin alışveriş tutum/ alışkanlıklarını ölçen bölüm için 0.927 ölçekte tüketicilerin satış geliştirme faaliyetlerinden etkilenme derecelerini ölçen ve 15 sorudan oluşan bölüm için 0.94 tüm ölçek için ve -demografik verilerle ilgili ifadelerin bulunduğu bölüm hariç- 0.956 gibi oldukça yüksek bir sonuç vermiştir.Araştırma ölçeğine ilişkin güvenirlilik testi sonuçları ve hesaplanan alfa katsayıları aşağıda Tablo 3' te verilmiştir:

Tablo 3:- Güvenilirlik Analizi Sonuçları.

\begin{tabular}{|l|l|l|}
\hline Değişkenler & Alfa Katsayıları & Güvenirlilik Düzeyi \\
\hline Satış Geliştirme & 94 & Yüksek Derecede Güvenilir \\
\hline Tutum Davranış & 92,7 & Yüksek Derecede Güvenilir \\
\hline Tüm Ölçek & 95,6 & Yüksek Derecede Güvenilir \\
\hline
\end{tabular}

Tablo 3’ten de görüleceği üzere ölçeğin güvenilirliği için kullanılan alfa katsayısı (Cronbach's Alpha) değeri 95.6 olarak hesaplanmıştır. Yüksek derecede güvenilir bir değer belirlenmesi sebebiyle alfa katsayısına göre içsel tutarlılığın sağlandığı söylenebilmektedir.

\section{Verilerin Kodlanması, Düzenlenmesi ve Analizi:-}

Anket formlarındaki sorulara verilen cevaplar kodlanarak "SPSS (Statistical Package for Social Sciences- Sosyal Bilimler İçin İstatistik Paketi) For Windows SPSS 21 Sürümü" ile analize tabi tutulmuştur. Adını "Statistical Package for Social Sciences" (Sosyal Bilimler İçin İstatistik Paketi) ifadesinin ilk harflerinden alan SPSS; istatistiksel bir analiz programıdır ve işletme, ekonomi, sosyoloji, psikoloji ve pazarlama gibi birçok alanda çeşitli amaçlar için yaygın olarak kullanılmaktadır (Altunışı ve diğerleri, 2010: 352). Ayrıca verilerin analizi ve grafiklere dönüştürülmesi gibi gerekli görülen durumlarda Excel 2010'dan yararlanılmıştır.

\section{Araştırma Bulgularının Değerlendirilmesi:-}

\section{Araştırma Örnekleminin Demografik Özellikleri:-}

Ankete katılan tüketicilerin demografik özelliklerine ait frekanslar ve ortalamalar aşağıda tablolarda gösterildiği gibidir.

Tablo 4 'ten görüldügü üzere, kadınların oranı \%59,6, erkeklerin oranı ise \%40,6 olup; kadın ve erkek sayılarının örneklem içindeki dağılımı birbirine yakındır; bekârlarınoranı \%64,3 iken evlilerin oranı \%35,7 dir. Katılımcılar 
içinde bekar olan tüketicilerin oranı evli tüketicilerin oranına göre daha fazladır. Ankete katılan tüketiciler nispeten gençlerden oluşmaktadır. Tüketiciler içinde $\% 29.2$ ile $15-18, \% 37.0$ ile 19-29, \%11.2 ile 30-39, \%13.5 ile 40-49, $\% 7.0$ ile 50-59 olup; ankete katılan tüketiciler içerisinde en az kesimi \%2.1 ile 60 yaş ve üzeri tüketiciler oluşturmaktadır. Bu rakamlardan anlaşılacağı üzere araştırmaya katılan tüketiciler içerisinde en büyük çoğunluğu \%37.0 oran ve 195 kişi ile 19-29 yaş aralığındaki genç tüketiciler; en düşük çoğunluğu ise \%2.1 oran ve 11 kişi ile 60 yaş ve üzeri tüketiciler oluşturmaktadır. Ankete cevap verenlerin en büyük kısmını \%39.5 ile lise mezunu, \%33.2 ile ikinci büyük kısmını üniversite mezunları oluşturmaktadır. \%14.2 ile önlisans mezunları üçüncü sırada, \%10.6 ile ilköğretim eğitim mezunları dördüncü sırada yer alırken, ankete katılanlar arasında en az kısmı \%2.5 ile lisansüstü mezunları oluşturmaktadır. Ankete katılanlar arasında en büyük kesimi \%34.2 oranı ile 2001 TL ve üzeri hane gelirine sahip olan kesim oluşturmaktadır. İkinci büyük kısmı \%31.1 ile 1501-2000 TL, üçüncü sırada \%23.0 ile 1001-1500 TL, dördüncü surada \%11.8 ile 0-1000 TL hane geliri hane geliri yer almaktadır. Ankete katılanlar arasında en büyük kesimi \%20.5 ile iş̧̧iler oluşturmaktadır. \%17.1 oranı ile devlet memurları ikinci sırayı takip ederken, üçüncü sırada \%14.8 oranı esnaflar, dördüncü sırada 14.6 ile emekliler, beşinci sırada $\% 7.0$ ile serbest meslek (Dr., Av., Müh.) sahipleri, altıncı sırada \%6.8 ile diğer meslek grupları, yedinci sırada \%6.1 ile ev hanımları, sekizinci sırada \%5.5 ile işletme sahipleri, dokuzuncu sırada \%4.7 ile iş̧̧iler, onuncu sırada \%2.5 ile kamu-özel idareciler, onbirinci sırada $\% 0.4$ ile işsizler yer almaktadır.

Tablo 4:- Araştırma Örnekleminin Demografik Özellikleri.

\begin{tabular}{|c|c|c|c|c|c|}
\hline \multicolumn{3}{|l|}{ CINSIYYT } & \multicolumn{3}{|c|}{ AYLIK HANE GELİRI } \\
\hline & SAYI & YÜZDE (\%) & & SAYI & YÜZDE (\%) \\
\hline Kadın & 314 & 59,6 & $0-1000$ & 62 & 11,8 \\
\hline Erkek & 213 & 40,4 & $1001-1500$ & 121 & 23,0 \\
\hline TOPLAM & 527 & 100,0 & $1501-2000$ & 164 & 31,1 \\
\hline \multicolumn{3}{|c|}{ MEDENİ DURUM } & 2001 ve üzeri & 180 & 34,2 \\
\hline \multicolumn{2}{|l|}{ SAYI } & YÜZDE (\%) & TOPLAM & 527 & 100,0 \\
\hline Bekar & 339 & 64,3 & \multicolumn{3}{|l|}{ MESLEK } \\
\hline Evli & 188 & 35,7 & & SAYI & YÜZDE (\%) \\
\hline TOPLAM & 527 & 100,0 & Serbest Meslek & 37 & 70 \\
\hline \multicolumn{3}{|l|}{ YAŞ } & (Dr. Av. Müh.) & TI & 1,0 \\
\hline & SAYI & YÜZDE (\%) & İşletme Sahibi & 29 & 5,5 \\
\hline $15-18$ & 154 & 29,2 & Esnaf & 78 & 14,8 \\
\hline $19-29$ & 195 & 37,0 & Kamu-Özel İdareci & 13 & 2,5 \\
\hline $30-39$ & 59 & 11,2 & Devlet Memuru & 90 & 17,1 \\
\hline $40-49$ & 71 & 13,5 & İşçi & 108 & 20,5 \\
\hline $50-59$ & 37 & 7,0 & Çiftçi & 25 & 4,7 \\
\hline $60+$ & 11 & 2,1 & Ev Hanımı & 32 & 6,1 \\
\hline TOPLAM & 527 & 100,0 & Emekli & 77 & 14,6 \\
\hline \multicolumn{3}{|c|}{ EĞİTİM DURUMU } & Diğer & 38 & 7,2 \\
\hline \multicolumn{2}{|l|}{ SAYI } & YÜZDE (\%) & TOPLAM & 527 & 100,0 \\
\hline İlköğretim & 56 & 10,6 & & & \\
\hline Lise & 208 & 39,5 & & & \\
\hline Önlisans & 75 & 14,2 & & & \\
\hline Lisans & 175 & 33,2 & & & \\
\hline Lisansüstü & 13 & 2,5 & & & \\
\hline TOPLAM & 527 & 100,0 & & & \\
\hline
\end{tabular}

\section{Faktör Analizive Sonuçları:-}

Faktör analizi, başlıca amacı aralarında ilişki bulunduğu düşünülen çok sayıdaki değişken arasındaki ilişkilerin anlaşılmasını ve yorumlanmasını kolaylaştırmak için daha az sayıdaki temel boyuta indirgemek ya da özetlemek olan bir grup çok değişkenli analiz tekniğine verilen genel bir isimdir. Etkin bir faktör analizinin toplam veri setini en iyi temsil edebilen ancak mümkün olduğunca az sayıda faktörden oluan bir çözüm olması arzu edilmektedir (Altunış1k ve diğerleri, 2010:262). Araştırmaya ilişkin yapılan öçekle ilgili faktör analizi ve KMO Barlett’s testi sonuçları aşağıda verilmiştir. 
Tüketicilerin Alışveriş Tutum ve Davranışlarını Ölçmeye Yarayan Ölçeğin Faktör Analizi:-

Tablo 5:- KMO Barlett's Testi.

\begin{tabular}{|l|l|l|}
\hline \multicolumn{2}{|l|}{ KMO and Bartlett's Test } & $\mathbf{9 3 7}$ \\
\hline Kaiser-Meyer-Olkin Measure of Sampling Adequacy. & Approx. Chi-Square & 8708,101 \\
\cline { 2 - 3 } Bartlett's Test of Sphericity & Df & 300 \\
\cline { 2 - 3 } & Sig. & 0,000 \\
\hline
\end{tabular}

Kaiser-Meyer-Olkin (KMO) örneklem yeterlilik testi (MSA); faktör analizinin uygunluğunu gösteren bir indistir. KMO değeri olarak 0.5-1.0 arası değerler kabul edilebilir olarak değerlendirilirken; 0.5 ' in altındaki değerler faktör analizinin söz konusu veri seti için uygun olmadığının göstergesidir. Ancak; genel olarak araştırmacılarca tatminkar olarak düşünülen asgari KMO değeri 0.7'dir (Aktaran: Altunışık,2010:265). MSA değerinin yorumlanmasında şu öneriler dikkate alınabilir. 0.8 ve üzeri değerler yüksek; 0.7 ve üzeri orta; 0.6 ve üzeri vasat; 0.5 ve üzeri zayıf; 0.5'in altı ise kabul edilemez (Aktaran: Altunışık, 2010:265). Tablo 5'ten de görüleceği üzere KMO değeri 0.937 çıkmış olup; veri seti faktör analizi için uygundur. Tüketicilerin alı̧̧veriş tutum ve davranışlarını ölçmeye yarayan bölüm için uygulanan faktör analizi sonuçları aşağıda Tablo 6'da yer almaktadır.

Tablo 6:- Faktör Analizi Sonuçları.

\begin{tabular}{|c|c|c|c|}
\hline \multicolumn{4}{|l|}{ Pattern Matrix $^{\mathrm{a}}$} \\
\hline & \multicolumn{3}{|c|}{ Component } \\
\hline & 1 & 2 & 3 \\
\hline 8.1. Alışverişten zevk alırım. & ,519 & & \\
\hline 8.2. Alıșveriș yapmak bana heyecan verir. & ,733 & & \\
\hline 8.3. Alışveriş yapmak bana her zaman ilgi çekici gelmiştir. & ,696 & & \\
\hline 8.4. Alışverişe sevdiklerimle gitmekten keyif alırım. & & & ,613 \\
\hline $\begin{array}{l}\text { 8.5. Alışverişe ailemle ya da arkadaşlarımla etkileşimde bulunmak, sosyalleşmek için } \\
\text { giderim. }\end{array}$ & & &, 597 \\
\hline 8.6. Bana göre tanıdıklarla alışverişe çıkmak onlarla vakit geçirmek için bir firsattır. & & & ,709 \\
\hline 8.7. Beraber alışveriş yapmak alışveriş yaptığım kişiyle samimiyetimi artırır. & & & ,704 \\
\hline 8.8. Alışveriş yaparken yeni insanlarla tanışmaktan hoşlanırım. & ,451 & & \\
\hline 8.9. Sıkıldığımda alışverişe gitmek kafamı rahatlatır. & 685 & & \\
\hline 8.10. Alışveriş yapmak bana günlük hayattan kaçma hissi verir. & ,792 & & \\
\hline 8.11. Alışveriş esnasında bütün sorunlarımı unutabiliyorum. & ,798 & & \\
\hline 8.12. Bana göre alışveriş; stresten kurtulmanın/ mutlu olmanın bir yoludur. &, 775 & & \\
\hline 8.13. Kendime iyi davranmak istediğim zaman alışverişe giderim. & ,777 & & \\
\hline 8.14. Yeni ürünlerin neler olduğunu görmek için alışverişe giderim. & ,732 & & \\
\hline 8.15. Modayı takip etmek için alışveriş yaparım. & ,777 & & \\
\hline $\begin{array}{l}\text { 8.16.Satın aldığım ürünler için değil alışverişin kendisi için alışverişe gitmekten } \\
\text { hoşlanırım. }\end{array}$ & ,716 & & \\
\hline $\begin{array}{l}\text { 8.17. Yaptı̆̆ım diğer aktivitelerle kıyaslandığında alışveriş yapmak gerçekten } \\
\text { eğlencelidir. }\end{array}$ & ,761 & & \\
\hline $\begin{array}{l}\text { 8.18. Başkaları için alışveriş yaparım; çünkü başkaları kendini iyi hissedince ben de } \\
\text { kendimi iyi hissediyorum. }\end{array}$ & & & ,623 \\
\hline 8.19. Arkadaşlarım ve ailem için alışveriş yapmaktan haz duyarım. & & & ,712 \\
\hline 8.20. Hediye alırken mükemmeli bulmak için zaman harcarım. & & & ,635 \\
\hline 8.21. Bir ürünü satın alırken öncelikle fiyatına dikkat ederim. & & 532 & \\
\hline 8.22. Alışverişte mutlaka pazarlık yaparım. & & ,506 & \\
\hline 8.23. Alışverişe çoğunlukla indirimli zamanlarda çıkarım. & & 840 & \\
\hline 8.24. Alışverişe çıktığımda indirimli ürünleri arayıp bulmak hoşuma gider. & & ,808 & \\
\hline 8.25. Promosyonlu ürünleri tercih ederim. & & ,777 & \\
\hline
\end{tabular}

Yapılan faktör analizi sonucunda değişkenler 3 faktör altında toplanmıştır. Birinci faktör altında toplanan değişkenler zevk almak, rahatlamak, fikir edinmek ile ilgilidir. Genellikle bireyler; rahatlamak için, yeni ürünlerin 
neler olduğunu görmek için, modayı takip etmek dolayısıyla fikir edinmek için alışverişe çıkmaktadır. Ayrıca birinci faktör altında kalan değişkenler tüketicilerin alışverişten zevk alması, heyecan verici ve ilgi çekici bulması, eğlenceli bulması ile ilgilidir. Fikir edinmek için alışverişe çıkmanın da bir çeşit rahatlama hissi vereceği göz önünde bulundurulursa bu faktör "rahatlamak için alışveriş" olarak adlandırılmıştır.İkinci faktör altında toplanan değişkenler; fiyata dikkat etme, pazarlık yapma, indiirmli zamanlarda alışverişe çıkma ve indirimli ürünleri arayıp bulmaktan duyulan hoşnutluk ve promosyonlu ürünleri tercih etme ile ilgili olduğundan; "değer elde etmek için alışveriş" olarak adlandırılmıştır.Üçüncü faktör altında yer alan değişkenler ise tüketicilerin alışverişe sevdikleri ile gitmelerinden keyif almaları, aile ve arkadaşları ile sosyalleşmek için gitmeleri, alışveriş yapılan kişiyle zaman geçirmek için bir firsat olarak görülmesi ve alışveriş yapılan kişiyle samimiyeti artırması ile ilgilidir. Diğer yandan bu faktörde yer alan değişkenler başkaları için alışveriş yapınca kendini iyi hissetme, başkaları için alışveriş yapmaktan zevk duyma, hediye alırken mükemmeli aramak için zaman harcama ile ilgilidir. Bireylerin başkalarına hediye almaları bireyler arasında iletişimi kuvvetlendirdiğinden bir çeşit sosyalleşme aracıdır. Dolayısıyla bu faktör "sosyalleşmek için alışveriş̧" olarak adlandırılmıştır.

Sonuç olarak; yapılan faktör analizi sonucu çıkan değişkenler üç faktör altında toplanmış olup; bunlar; rahatlamak için allşveriş, değer elde etmek için alışveriş ve sosyalleşmek için alışveriştir. Faktör analizi sonucunun orijinal ölçekten farklı olarak üç faktörlü olmasının sebebi araştırmanın tamamen başka bir ülke olan Türkiye'de yapılması ve dolayısıyla demografik, sosyo-kültürel, ekonomik farklılıkların olmasıdır. Bir ülkenin ekonomik durumunun, o ülkede yaşayan bireylerin kültürünü ve ekonomik durumunu etkilediği, dolayısıyla satın alma alışkanlıklarını etkilediği göz önünde bulundurulursa sonuçların bu şekilde farklı çıkmasının oldukça doğal olduğu görülecektir.

Tüketicilerin Satış Geliştirme Tekniklerinden Etkilenme Derecelerini Ölçmeye Yarayan Ölçeğin Faktör Analizi:-

Tablo 7:- KMO Barlett's Testi.

\begin{tabular}{|l|l|l|}
\hline \multicolumn{2}{|l|}{ KMO and Bartlett's Test } &, 917 \\
\hline Kaiser-Meyer-Olkin Measure of Sampling Adequacy. & Approx. Chi-Square & 5224,631 \\
\hline Bartlett's Test of Sphericity & df & 105 \\
\cline { 2 - 3 } & Sig. & 0,000 \\
\hline
\end{tabular}

Yukarıda da açıklandığı üzere Kaiser-Meyer-Olkin (KMO) örneklem yeterlilik testi (MSA); faktör analizinin uygunluğunu gösteren bir indis olup; KMO değeri olarak 0.5-1.0 arası değerler kabul edilebilir olarak değerlendirilmektedir. 0.5'in altındaki değerler faktör analizinin söz konusu veri seti için uygun olmadığının göstergesi iken; genel olarak araştırmacılarca tatminkar olarak düşünülen asgari KMO değeri 0.7 'dir.MSA değerinin yorumlanmasında şu öneriler dikkate alınabilir. 0.8 ve üzeri değerler yüksek; 0.7 ve üzeri orta; 0.6 ve üzeri vasat; 0.5 ve üzeri zayıf; 0.5 'in altı ise kabul edilemez (Aktaran: Altunışık, 2010:265).Tablo 7'den de görüleceği üzere KMO değeri 0.917 çıkmış olup; veri seti faktör analizi için uygundur. Tüketicilerin alışveriş tutum ve davranışlarını ölçmeye yarayan bölüm için uygulanan faktör analizi sonuçları aşağıda Tablo 8'de yer almaktadır.

Tablo 8:- Faktör Analizi Sonuçları.

\begin{tabular}{|l|l|l|l|}
\hline Pattern Matrix & \multicolumn{3}{l|}{ Component } \\
\cline { 2 - 4 } & 1 & 2 & 3 \\
\hline 9.1. Promosyonlar yeni ürünleri denememi sağlar. & & &, 477 \\
\hline 9.2. Promosyonlar kendimi iyi hissetmemi sağlıyor. & & &, 606 \\
\hline 9.3. Promosyonlar sayesinde ödeyeceğim paradan tasarruf ettiğimi düşünüyorum. & &, 705 & \\
\hline 9.4. Promosyonları takip ettiğim için çevremdeki insanlar beni takdir eder. & & &, 716 \\
\hline 9.5. İhtiyacım olmasa bile bir ürünü promosyon olduğu için satın alabilirim. & & &, 803 \\
\hline 9.6. Aklımdaki marka yerine promosyonlu markayı almayı tercih ederim. & & &, 559 \\
\hline 9.7. İşletmelerin yapmış olduğu fiyat indirimleri satın alma kararımı etkiler. & &, 799 & \\
\hline 9.8. Bir ürün fiyatına iki ürün kampanyası rakip markayı tercih etmemde etkili olur. & &, 811 & \\
\hline 9.9. Bedava ürün verilmesi satın alma kararımı etkiler. & &, 780 & \\
\hline 9.10. Yarışma ve çekiliş̧ler satın alma kararımı etkiler. &, 685 & & \\
\hline 9.11. Dağıtılan kuponlar satın alma kararımı etkiler. &, 853 & & \\
\hline
\end{tabular}




\begin{tabular}{|l|c|c|c|}
\hline 9.12. İşletmelerin hediye vermesi satın alma kararımı etkiler. &, 813 & & \\
\hline 9.13. İşletmelerin harcamalara verdiği ekstra paralar satı alma kararımı etkiler. &, 842 & & \\
\hline $\begin{array}{l}\text { 9.14. Promosyon için dağıtılan el ilanı, broşür, insert vb... satı alma kararımı etkiler. } \\
\text { 9.15. Cep telefonuma ve elektronik postama gelen promosyon haberleri satın alma } \\
\text { kararımı etkiler. }\end{array}$ &, 822 & & \\
\hline
\end{tabular}

Yapılan faktör analizi sonucunda değişkenler 3 faktör altında toplanmıştır. Birinci faktörde yer alan değişkenler; işletmelerin uygulamış olduğu satış geliştirme teknikleri ile ilgili olduğundan bu faktör; "satış geliş̧tirme" faktörü olarak adlandırılmıştır. İkinci faktörde yer alan değişkenler işletmelerin yapmış olduğu fiyat indirimleri, bedava ürün verme, bir ürün fiyatına iki ürün alma ve promosyonlar sayesinde tasarruf etme ile ilgili olduğundan bu factor "bütçe" faktörü olarak adlandırılmıştır. Üçüncü faktörde yer alan değişkenler genellikle tüketicilerin satış geliştirme tekniklerine bakış açıları ile ilgili olduğundan; bu faktör "genel izlenim" olarak adlandırılmıştır. Dolayısıyla yapılan faktör analizi sonucu çıkan faktörler; satış geliştirme, bütçe, genel izlenim şeklindedir.

\section{Araştırmaya Katılan Tüketicilerin Her Bir Soruya Verdikleri Cevapların Ortalamaları:-}

Tek grup T testinde amaç üzerinde çalışlan değişkenin öngörülen veya hipotez testinde öngörülen bir değerden farklı olup olmadığının araştırılmasında kullanılmaktadır (Altunışık ve diğerleri, 2010:184). Araştırmaya katılan tüketicilerin alışveriş tutum/davranışları ilgili ifadelerde her bir soruya verdikleri cevapların ortalamaları ve standart sapmaları aşağıda Tablo 9'da gösterilmiştir.

Tablo 92:- Araştırmaya Katılanların Alışveriş Tutum/Davranışları İlgili İfadelerde Her Bir Soruya Verdikleri Cevapların Ortalamaları ve Standart Sapmaları

\begin{tabular}{|c|c|c|c|}
\hline Tek Grup T Testi & Sayı & Ortalama & Standart Sapma \\
\hline 8.1. Alışverișten zevk alırım. & 527 & 4,169 & 8850 \\
\hline 8.2. Alışveriş yapmak bana heyecan verir. & 527 & 3,915 & ,9896 \\
\hline 8.3. Alışveriş yapmak bana her zaman ilgi çekici gelmiştir. & 527 & 3,748 & 1,0799 \\
\hline 8.4. Alışverişe sevdiklerimle gitmekten keyif alırım. & 527 & 3,917 & 1,2640 \\
\hline $\begin{array}{l}\text { 8.5. Alışverişe ailemle ya da arkadaşlarımla etkileşimde bulunmak, } \\
\text { sosyalleşmek için giderim. }\end{array}$ & 527 & 3,681 & 1,1205 \\
\hline $\begin{array}{l}\text { 8.6. Bana göre tanıdıklarla alışverişe çıkmak onlarla vakit geçirmek } \\
\text { için bir fırsattır. }\end{array}$ & 527 & 3,691 & 1,1721 \\
\hline $\begin{array}{l}\text { 8.7. Beraber alışveriş yapmak alışveriş yaptığım kişiyle samimiyetimi } \\
\text { artırır. }\end{array}$ & 527 & 3,839 & 1,0440 \\
\hline 8.8. Alışveriş yaparken yeni insanlarla tanışmaktan hoşlanırım. & 527 & 3,843 & 1,1286 \\
\hline 8.9.Sıkıldığımda alışverişe gitmek kafamı rahatlatır. & 527 & 3,934 & 1,0668 \\
\hline 8.10. Alışveriş yapmak bana günlük hayattan kaçma hissi verir. & 527 & 3,531 & 1,1903 \\
\hline 8.11. Alışveriş esnasında bütün sorunlarımı unutabiliyorum. & 527 & 3,590 & 1,1889 \\
\hline $\begin{array}{l}\text { 8.12. Bana göre alışveriş; stresten kurtulmanın/ mutlu olmanın bir } \\
\text { yoludur. }\end{array}$ & 527 & 3,742 & 1,1277 \\
\hline 8.13. Kendime iyi davranmak istediğim zaman alışverişe giderim. & 527 & 3,732 & 1,0494 \\
\hline 8.14. Yeni ürünlerin neler olduğunu görmek için alışverişe giderim. & 527 & 3,924 & ,9720 \\
\hline 8.15. Modayı takip etmek için alışveriş yaparım. & 527 & 3,228 & 1,2717 \\
\hline $\begin{array}{l}\text { 8.16.Satın aldığım ürünler için değil alışverişin kendisi için alışverişe } \\
\text { gitmekten hoşlanırım. }\end{array}$ & 527 & 4,129 & ,9683 \\
\hline $\begin{array}{l}\text { 8.17.Yaptığım diğer aktivitelerle kıyaslandığında alışveriş yapmak } \\
\text { gerçekten eğlencelidir. }\end{array}$ & 527 & 4,268 & ,8333 \\
\hline $\begin{array}{l}\text { 8.18. Başkaları için alışveriş yaparım; çünkü başkaları kendini iyi } \\
\text { hissedince ben de kendimi iyi hissediyorum. }\end{array}$ & 527 & 3,685 & 1,1368 \\
\hline 8.19. Arkadaşlarım ve ailem için alışveriş yapmaktan haz duyarım. & 527 & 4,120 & ,8358 \\
\hline 8.20. Hediye alırken mükemmeli bulmak için zaman harcarım. & 527 & 4,292 & ,7231 \\
\hline 8.21. Bir ürünü satın alırken öncelikle fiyatına dikkat ederim. & 527 & 4,336 & ,6888 \\
\hline 8.22. Alışverişte mutlaka pazarlık yaparım. & 527 & 4,249 & 8069 \\
\hline 8.23. Alışverişe çoğunlukla indirimli zamanlarda çıkarım. & 527 & 4,393 & 6344 \\
\hline 8.24. Alışverişe çıktığımda indirimli ürünleri arayıp bulmak hoşuma & 527 & 4,294 & ,8174 \\
\hline
\end{tabular}


gider. 8.25. Promosyonlu ürünleri tercih ederim.

527

4,309

7659

Tablo 9'dan da anlaşıldığı üzere kullanılan ölçeğe göre alınan cevaplar 5 üzerinden değerlendirilmiștir. 5'li likert ölçeğinin puanlarında; "5:Kesinlikle Katılıyorum”, “4:Katılıyorum”, “3: Kararsızım”, "2:Katılmıyorum”, "1:Kesinlikle Katılmıyorum” a karşılık gelmektedir. Buna göre ifadeler değerlendirildiğinde ölçekteki her bir ifadeye katılım oranına bakılacak olursa;

- “Alışverişten zevk alırım." ifadesine katılım oranı 4.169 olup; "Katılıyorum” ile "Kesinlikle Katılıyorum” arasında bir puana denk gelmektedir. Bu ifade "Katılıyorum" şeklinde yorumlanabilir. Bu bulgulardan hareketle; H1a Hipotezi kabul edilmiştir. Araştırmaya katılan tüketicilerin alışverişten zevk alma düzeyi yüksektir.

- "Promosyonlu ürünleri tercih ederim." İfadesine katılım oranı 4.309 olup; bu ifade "Katılıyorum” ile "Kesinlikle Katılıorum" arasında bir puana denk gelmektedir. Bu ifade "Katılıyorum” şeklinde yorumlanabilir. Bu bulgulardan hareketle H1bHipotezi kabul edilmiştir. Araştırmaya katılan tüketicilerin promosyonlu ürünleri tercih etme düzeyi yüksektir.

\section{Korelasyon Analizi:-}

Korelasyon analizi, aralık ve rasyo seviyesinde ölçülmüş iki değişken arasındaki ilişkinin veya bağımlılığın şiddetini belirlemeye yönelik bir analiz tekniğidir. Korelasyon analizi neticesinde hesaplanan korelasyon katsayısı $\mathrm{r}$ ile gösterilmektedir ve -1 ile +1 arasında değerler alabilir. Katsayının +1 olması iki değişken arasında mükemmel bir doğrusal ilişkinin (x değeri 1birim artarken, y değeri de bir birim artmaktadır) olduğunu gösterirken, katsayının -1 olması ise değişkenler arasında mükemmel bir ilişkinin olduğu fakat ilişkinin ters yönlü olduğu ( $\mathrm{x}$ değeri artarken y değeri azalmaktadır) anlamına gelmektedir. Katsayının sıfır olması durumunda ise iki değişken arasında herhangi bir açık/görülebilir bir ilişkinin olmadığı anlamına gelmektedir. Korelasyon katsayısı r sadece iki değişken arasındaki ilişkinin şiddeti konusunda bilgi vermektedir. Değişkenler arasındaki ilişkinin türü ya da formülasyonu hakkında bilgi vermez (Altunışık ve diğerleri, 2010:226-227).Tüm bu açıklamalar 1şığında araştırmanın hipotezlerine ilişkin korelasyon analizleri ve sonuçları aşağıda gösterilmiştir.

Tablo 10:- H3a Hipotezine Yönelik Korelasyon Analizi

\begin{tabular}{|l|l|l|l|}
\hline \multicolumn{2}{|c|}{ Correlations } & $\begin{array}{l}8.21 \text {. Bir ürünü } \\
\text { satın alırken } \\
\text { öncelikle fiyatına } \\
\text { dikkat ederim. }\end{array}$ & $\begin{array}{l}\text { 9.7. İşletmelerin yapmış } \\
\text { olduğu fiyat indirimleri } \\
\text { satın alma kararımı etkiler. }\end{array}$ \\
\hline $\begin{array}{l}8.21 . \quad \text { Bir ürünü satın alırken } \\
\text { öncelikle fiyatına dikkat ederim. }\end{array}$ & $\begin{array}{l}\text { Pearson } \\
\text { Correlation }\end{array}$ & 1 & $\mathbf{1 0 3}^{*}$ \\
\cline { 2 - 4 } & Sig. (2-tailed) & &, 018 \\
\cline { 2 - 4 } & $\mathrm{N}$ & 527 & 527 \\
\hline $\begin{array}{l}\text { 9.7. İşletmelerin yapmış olduğu } \\
\text { fiyat indirimleri satın alma kararımı } \\
\text { etkiler. }\end{array}$ & $\begin{array}{l}\text { Pearson } \\
\text { Correlation }\end{array}$ &, $103^{*}$ & 1 \\
\cline { 2 - 4 } & Sig. (2-tailed) &, 018 & 527 \\
\cline { 2 - 3 } & $\mathrm{N}$ & 527 & \\
\hline *. Correlation is significant at the 0.05 level (2-tailed). & & \\
\hline
\end{tabular}

Tablo 10'dan da anlaşılacağ1 üzere “bir ürünü satın alırken öncelikle fiyatına dikkat ederim” ifadesine katılmaları ile "işletmelerin yapmış olduğu fiyat indirimleri satın alma kararımı etkiler" ifadesine katılmaları korelasyon analizi ile incelenmiştir ve bu ilişki istatistiki açıdan da anlamlıdır $(\mathrm{r}=0,103)$. Bu bulgulardan hareketle bir ürün satın alırken öncelikle fiyatına dikkat eden tüketiciler işletmelerin yapmış olduğu fiyat indirimlerinden de etkilenmektedir şeklinde yorum yapılabilir. Bu sonuca bağlı olarak H3a hipotezi kabul edilmiştir.

Tablo 11:- H3b Hiptezine Yönelik Korelasyon Analizi.

\section{Correlations}

8.25.Promosyonlu

ürünleri tercih ederim.
9.1.Promosyonlar

yeni ürünleri

denememi sağlar. 


\begin{tabular}{|l|l|l|l|}
\hline $\begin{array}{l}\text { 8.25.Promosyonlu ürünleri } \\
\text { tercih ederim. }\end{array}$ & Pearson Correlation & 1 & $\mathbf{0 7 5}$ \\
\cline { 2 - 4 } & Sig. (2-tailed) & &, 083 \\
\cline { 2 - 4 } & $\mathrm{N}$ & 527 & 527 \\
\hline $\begin{array}{l}\text { 9.1.Promosyonlar yeni ürünleri } \\
\text { denememi sağlar. }\end{array}$ & Pearson Correlation &, 075 & 1 \\
\cline { 2 - 4 } & Sig. (2-tailed) &, 083 & 527 \\
\cline { 2 - 4 } & $\mathrm{N}$ & 527 & \\
\hline
\end{tabular}

Tablo 11'den de anlaşılacağı üzere "promosyonlu ürünleri tercih ederim" ifadesine katılmaları ile "promosyonlar yeni ürünleri denememi sağlar" ifadesine katılmaları korelasyonanalizi ile incelenmiştir ve bu ilişki istatistiki açıdan da anlamlıdır $(\mathrm{r}=0,75)$. Bu bulgulardan hareketle promosyonlu ürünleri tercih eden tüketiciler promosyonlar sayesinde yeni ürünleri denemektedir. Bu sonuca göre $\mathrm{H} 3 b$ hipotezi kabul edilmiştir.

Tablo 12:- H3c Hipotezine Yönelik Korelasyon Analizi

\begin{tabular}{|c|c|c|c|}
\hline \multicolumn{4}{|l|}{ Correlations } \\
\hline & & 8.25.Promosyonlu & 9.2.Promosyonlar \\
\hline & & $\begin{array}{l}\text { ürünleri tercih } \\
\text { ederim. }\end{array}$ & hissetmemi sağlıyor. \\
\hline \multirow{3}{*}{$\begin{array}{l}\text { 8.25.Promosyonlu } \\
\text { ürünleri tercih } \\
\text { ederim. }\end{array}$} & Pearson Correlation & 1 &, $134^{* *}$ \\
\hline & Sig. (2-tailed) & &, 002 \\
\hline & $\mathrm{N}$ & 527 & 527 \\
\hline \multirow{3}{*}{$\begin{array}{l}\text { 9.2.Promosyonlar } \\
\text { kendimi iyi } \\
\text { hissetmemi } \\
\text { sağliyor. }\end{array}$} & Pearson Correlation &, $134^{* * *}$ & 1 \\
\hline & Sig. (2-tailed) & ,002 & \\
\hline & $\mathrm{N}$ & 527 & 527 \\
\hline
\end{tabular}

Tablo 12'den de anlaşılacağı üzere "promosyonlu ürünleri tercih ederim" ifadesine katılmaları ile "promosyonlar kendimi iyi hissetmemi sağlar" katılmaları korelasyon analizi ile incelenmiştir ve bu ilişki istatiski açıdan anlamlıdır $(\mathrm{r}=0,134)$. Bu bulgulardan hareketle göre tüketiciler promosyonların kendilerini iyi hissettirdiğini düşünmektedir şeklinde yorum yapılabilir. H3c hipotezi kabul edilmiştir.

Tablo 133:- H3d Hipotezine Yönelik Korelasyon Analizi.

\begin{tabular}{|c|c|c|c|}
\hline \multicolumn{4}{|l|}{ Correlations } \\
\hline & & $\begin{array}{l}\text { 8.25. Promosyonlu } \\
\text { ürünleri tercih ederim. }\end{array}$ & $\begin{array}{l}\text { 9.4.Promosyonları takip } \\
\text { ettiğim için çevremdeki } \\
\text { insanlar beni takdir eder. }\end{array}$ \\
\hline \multirow{3}{*}{$\begin{array}{l}\text { 8.25.Promosyonlu ürünleri } \\
\text { tercih ederim. }\end{array}$} & Pearson Correlation & 1 &, $113^{* * *}$ \\
\hline & Sig. (2-tailed) & & ,009 \\
\hline & $\mathrm{N}$ & 527 & 527 \\
\hline \multirow{3}{*}{$\begin{array}{l}\text { 9.4.Promosyonları takip ettiğim } \\
\text { için çevremdeki insanlar beni } \\
\text { takdir eder. }\end{array}$} & Pearson Correlation &, $113^{* *}$ & 1 \\
\hline & Sig. (2-tailed) & .009 & \\
\hline & $\mathrm{N}$ & 527 & 527 \\
\hline
\end{tabular}

Tablo 13'ten de anlaşılacağı üzere "promosyonlu ürünleri tercih ederim"ifadesine katılamalrı ile "promosyonları takip ettiğim için çevremdeki insanlar beni takdir eder"ifadesine katılmaları korelasyon analizi ile incelenmiştir ve bu ilişki istatistiki açıdan anlamlıdır $(0,113)$. Bu sonuca göre promosyonlu ürünleri tercih eden tüketiciler promosyonları takip ettiği için çevresinden takdir görmektedir. H3d hipotezi kabul edilmiştir.

Tablo 14:- H3e Hipotezine Yönelik Korelasyon Analizi

\begin{tabular}{|l|l|l|l|}
\hline \multicolumn{2}{|l|}{ Correlations } & $\begin{array}{l}\text { 9.4.Promosyonları } \\
\text { takip ettiğim için } \\
\text { çevremdeki insanlar } \\
\text { beni takdir eder. }\end{array}$ & $\begin{array}{l}\text { 8.25.Promosyonlu } \\
\text { ürünleri teri } \\
\text { ederim. }\end{array}$ \\
\hline $\begin{array}{l}\text { 9.4.Promosyonları takip ettiğim } \\
\text { için çevremdeki insanlar beni }\end{array}$ & Pearson Correlation & 1 & $\mathbf{, 1 1 3}$ \\
\cline { 2 - 4 } & Sig. (2-tailed) & &, 009 \\
\hline
\end{tabular}




\begin{tabular}{|l|l|l|l|}
\hline takdir eder. & $\mathrm{N}$ & 527 & 527 \\
\hline $\begin{array}{l}\text { 8.25.Promosyonlu ürünleri } \\
\text { tercih ederim. }\end{array}$ & Pearson Correlation &, $113^{* *}$ & 1 \\
\cline { 3 - 4 } & Sig. (2-tailed) &, 009 & \\
\cline { 2 - 4 } & $\mathrm{N}$ & 527 & 527 \\
\hline
\end{tabular}

Tablo 14'ten de anlaşılacağı üzere "promosyonları takip ettiğim için çevremdeki insanlar beni takdir eder"ifadesine katılmaları ile "promosyonlu ürünleri tercih ederim" ifadesine katılmaları arasındaki ilişki korelasyon analizi ile incelenmiştir ve bu ilişki istatistiksel açıdan anlamlıdır $(\mathrm{r}=0,113)$. Bu sonuca göre promosyonlu ürünleri tercih ettiği için takdir edildiğinidüşünenler promosyonlu ürünleri tercih etmektedir şeklinde yorum yapılabilir. H3 e hipotezi kabul edilmiştir.

Tablo 15:- H3f Hiptezine Yönelik Korelasyon Analizi

\begin{tabular}{|l|l|l|l|}
\hline \multicolumn{2}{|l|}{ Correlations } & $\begin{array}{l}\text { 8.25.Promosyonlu } \\
\text { ürünleri tercih } \\
\text { ederim. }\end{array}$ & $\begin{array}{l}\text { 9.6.Aklimdaki marka yerine } \\
\text { promosyonlu markayi almay1 } \\
\text { tercih ederim. }\end{array}$ \\
\hline $\begin{array}{l}\text { 8.25.Promosyonlu ürünleri tercih } \\
\text { ederim. }\end{array}$ & $\begin{array}{l}\text { Pearson } \\
\text { Correlation }\end{array}$ & 1 &, 033 \\
\cline { 2 - 4 } & Sig. (2-tailed) & &, 451 \\
\cline { 2 - 5 } & $\mathrm{N}$ & 527 & 527 \\
\hline $\begin{array}{l}\text { 9.6.Aklımdaki marka yerine } \\
\text { promosyonlu markay1 almay1 } \\
\text { tercih ederim. }\end{array}$ & $\begin{array}{l}\text { Pearson } \\
\text { Correlation }\end{array}$ &, 033 & 1 \\
\cline { 2 - 5 } & Sig. (2-tailed) &, 451 & 527 \\
\cline { 2 - 5 } & $\mathrm{N}$ & 527 & \\
\hline
\end{tabular}

Tablo 15 'ten de anlaşlacağı üzere "promosyonlu ürünleri tercih ederim"ifadesine katılmaları ile "aklımdaki marka yerine promosyonlu markayı almayı tercih ederim"ifadesine katılmaları arasındaki ilişki korelasyon analizi ile incelenmiştir ve bu ilişki istatistiki açıdan anlamlıdır $(0,033)$. Bu bulgulardan hareketle promoyonlu ürünleri tercih eden tüketiciler aklında olan marka yerine promosyonlu markayı tercih etmektedir şeklinde yorum yapılabilir. H4f hipotezi kabul edilmiştir.

Tablo 16:- H3g Hipotezine Yönelik KorelasyonAnalizi

\begin{tabular}{|l|l|l|l|}
\hline Correlations & $\begin{array}{l}8.25 . \\
\text { Promosyonlu } \\
\text { ürünleri tercih } \\
\text { ederim. }\end{array}$ & $\begin{array}{l}\text { 9.5. İhtiyacım olmasa } \\
\text { bile bir ürünü } \\
\text { promosyon olduğu için } \\
\text { satın alabilirim. }\end{array}$ \\
\hline $\begin{array}{l}\text { 8.25.Promosyonlu ürünleri tercih } \\
\text { ederim. }\end{array}$ & Pearson Correlation & 1 &, $104^{*}$ \\
\cline { 2 - 4 } & Sig. (2-tailed) & &, 017 \\
\cline { 2 - 4 } & $\mathrm{N}$ & 527 & 527 \\
\hline $\begin{array}{l}\text { 9.5.İhtiyacım olmasa bile bir ürünü } \\
\text { promosyon olduğu için satın } \\
\text { alabilirim. }\end{array}$ & Pearson Correlation &, $104^{*}$ & 1 \\
\cline { 2 - 4 } & Sig. (2-tailed) & 017 & 527 \\
\cline { 2 - 5 } & $\mathrm{N}$ & 527 & \\
\hline
\end{tabular}

Tablo 16'dan da anlaşılacağı üzere "promosyonlu ürünleri tercih ederim" ifadesine katılmaları ile "ihtiyacım olmasa bile bir ürünü promosyon olduğu içinsatın alabilirim" ifadesine katılmaları arasındaki ilişki korelasyon analizi ile incelenmiştir ve bu ilişki istatistiksel açıdan anlamlıdır $(0,104)$. Bu sonuca göre promosyonlu ürünleri tercih eden tüketiciler ihtiyaçları olmasa bile bir ürünü promosyonlu olduğu için satın almaktadır şeklinde yorum yapılabilir. H3g hipotezi kabul edilmiştir.

Hipotezlere Yönelik Yapılan Analizler ve Sonuçları:-

Bu bölümde araştırmanın hipotezlerine yönelik yapılan hipotezler ve sonuçları tablolar halinde gösterilmiştir. 
Tablo 174:-H1 Hipotezine Yönelik Yapılan Analizler ve Sonuçları

\begin{tabular}{|c|c|c|c|}
\hline & Yapılan Analiz & Değer & Sonuç \\
\hline $\begin{array}{l}\text { H1a: Araştırmaya katılan tüketicilerin alışverişten zevk alma } \\
\text { düzeyi yüksektir. }\end{array}$ & Tek Grup T Testi & Mean:4.169 & Kabul \\
\hline $\begin{array}{l}\text { H1b: Araştırmaya katılan tüketicilerin alışverişten heyecan } \\
\text { duyma düzeyi yüksektir. }\end{array}$ & Tek Grup T Testi & Mean:3.915 & Kabul \\
\hline
\end{tabular}

Tablo 18:- H2 Hipotezine Yönelik Yapılan Analizler ve Sonuçları

\begin{tabular}{|c|c|c|c|c|}
\hline \multicolumn{5}{|c|}{ 2: Satış geliştirme teknikleri ile hedonik tüketim davranışları arasında anlamlı bir ilişki bulunmaktadır. } \\
\hline & Yapılan Analiz & Değer & & Sonuç \\
\hline $\begin{array}{l}\text { H2a: Bir ürünü satın alıken öncelikle fiyatına dikkat } \\
\text { eden tüketiciler, satın alma kararlarında işletmelerin } \\
\text { yapmış olduğu fiyat indirimlerinden etkilenmektedir }\end{array}$ & Korelasyon Analizi & $\begin{array}{l}\text { Pearson } \\
0.103\end{array}$ & Korelasyon: & Kabul \\
\hline $\begin{array}{l}\text { H2b: Promosyonlu ürünleri tercih eden tüketiciler, } \\
\text { promosyonlar sayesinde yeni ürünleri denemektedir. }\end{array}$ & Korelasyon Analizi & $\begin{array}{l}\text { Pearson } \\
0.075\end{array}$ & Korelasyon: & Kabul \\
\hline $\begin{array}{l}\text { H2c: Promosyonlu ürünleri tercih eden tüketiciler, } \\
\text { promosyonlar sayesinde kendini iyi hissetmektedir. }\end{array}$ & Korelasyon Analizi & $\begin{array}{l}\text { Pearson } \\
0.134\end{array}$ & Korelasyon: & Kabul \\
\hline $\begin{array}{l}\text { H2d: Promosyonları takip ettiği için çevresindeki } \\
\text { insanların kendisini takdir ettiğini düşünen } \\
\text { tüketiciler, promosyonlu ürünleri tercih etmektedir. }\end{array}$ & Korelasyon Analizi & $\begin{array}{l}\text { Pearson } \\
0.113\end{array}$ & Korelasyon: & Kabul \\
\hline $\begin{array}{l}\text { H2e: Promosyonlu ürünleri tercih eden tüketiciler, } \\
\text { promosyonlar1 takip ettiği için çevresindeki } \\
\text { insanların kendisini takdir ettiğini düşünmektedir. }\end{array}$ & Korelasyon Analizi & $\begin{array}{l}\text { Pearson } \\
0.113\end{array}$ & Korelasyon: & Kabul \\
\hline $\begin{array}{l}\text { H2f: Promosyonlu ürünleri tercih eden tüketiciler, } \\
\text { ihtiyacı olmasa bile bir ürünü promosyon olduğu } \\
\text { için satın almaktadır. }\end{array}$ & Korelasyon Analizi & $\begin{array}{l}\text { Pearson } \\
0.033\end{array}$ & Korelasyon: & Kabul \\
\hline
\end{tabular}

\section{Sonuc:-}

$\mathrm{Bu}$ araştırma ile geliştirme tekniklerininhazcı (hedonik) tüketim üzerindeki etkisini ölçmek amaçlanmıştır. Bu amaçla oluşturulan anket soruları ile yüz yüze anket çalışmasını içeren bir saha çalışması yapılmıștır. Araştırmanın ana kitlesini Konya ili merkezinde yaşayan tüm tüketiciler oluşturmaktadır. Çalışmanın örnek kitlesini ise Konya ili merkezde yaşayan ana kitlenin özeliklerini yansitabileceği düşünülen büyük alışveriş merkezlerinde alışveriş yapan 527 tüketici oluşturmaktadır.Bu araştırma ile elde edilen bulguları aşağıdaki şekilde özetlemek mümkündür:Araştırmanın alışveriş tutum/davranış ve yaşam tarzını ölçmeye yarayan bölümde yer alan sorulara tüketicilerin büyük çoğunluğunun katıldığ 1 görülmüsstür. Araştırmanın bu bölümünde yer alan soruların her biri hedonik tüketim alışkanlıklarını yansıttığı için araştırmaya katılan tüketicilerin hedonik tüketici olduğu ya da bir başka deyişle hedonik tüketim davranışı sergilediği söylenebilir. Araştırmaya katılan tüketiciler arkadaş ve aile ile alışverişe sosyalleşmek için çıkmak, tanıdıklarla vakit geçirmek için alışverişe çıkmak, alışverişin alışverişe birlikte çıkılan kişi ile samimiyeti artırdığı görüşünde olmak, alışveriş esnasında yeni insanlarla tanışmaktanhoşlanmak ile ilgili ifadelere katılmakla "sosyalleşmek için alışveriş"yaptıklarını göstermişlerdir. Aynı şekilde alışverişin rahatlatıcı olduğu fikrine sahip olmak, günlük hayattan kaçma hissi vermesi, alışveriş esnasında tüm sorunların unutulabildiği, alışverişin stresten kurtulma/mutlu olmanın bir yolu olduğu fikri ve kişinin kendine iyi davranmak istediğinde alışverişe gitmesi ile ilgili ifadelere katılan tüketiciler "rahatlamak için alışveriş" "yapmaktadır.Tüketicilerin yeni ürünlerin neler olduğu görmek için alışverişe gitmesi, modayı takip etmek için alışverişe gitmesi, satın alınan ürün için değil alışverişin kendisi için alışverişe gitmekten hoşlanılması ve alışverişi eğlenceleri bulması "fikir edinmek için alışveriş" yaptıklarını göstermektedir.Tüketicilerin başkaları alışveriş yapmakla kendini iyi hissetmesi, arkadaş ve aile için alışveriş yapmaktan haz duyması, hediye alırken mükemmeli bulmak için zaman harcaması tüketicilerin "başkalarını mutlu etmek için alışveriş" yaptı̆̆ını göstermektedir.Tüketicilerin satın alma kararlarında öncelikle fiyata dikkat etmeleri, pazarlık yapmaları, alışverişe çoğunlukla indirimli zamanlarda çıkmaları, alışverişte indirimli ürünleri arayıp bulmaktan hoşlanmaları ve promosyonlu ürünleri tercih etmeleri ise "değer elde etmek için allşveriş"yaptıklarının bir göstergesidir.Araştırmaya katılan tüketicilerin alışveriş tutum/davranış ve yaşam tarzı ile ilgili bölümdeki her bir soruya katılma derecelerine bakıldığında "başkalarını mutlu etmek için alışveriş̧"ve "değer elde etmek için alışveriş" ile ilgili sorulara katılım 
oranının yüksek olduğu görülmektedir. Bu sonuca bakılarak araştırmaya katılan tüketiciler en çok "başkalarını mutlu etmek için alışveriş" ve "değer elde etmek için allşveriş"yapmaktadır.

Araştırmanın satış geliştirme tekniklerinden etkilenmelerini ölçmeye yarayan bölümde yer alan sorulara tüketicilerin büyük çoğunluğunun katıldığı görülmüştür. B1 bölümde yer alan ifadeler; tüketiciler tarafından en genel haliyle "promosyon" olarak adlandırılan ve her biri birer satış geliştirme tekniği olan kuponlar, para iadeleri, yarışmalar/çekilişler, hediye verme, fiyat indirimleri ve insertler ile ilgili ifadelerdir. Dolayısıyla araştırmaya katılan tüketicilerin her bir ifadeye katılması satış geliştirme tekniklerinden etkilendiklerini göstermektedir. Tüketiciler kuponlardan, para iadelerinden, yarışma ve çekilişlerden, işletmelerin hediye vermesinden, fiyat indirimlerinden ve dağıtılan broşür, insert vb... satış geliş̧irme tekniklerinden etkilenmektedir. Araştırmanın bu bölümünde yer alan sorulara katılma derecelerine bakıldı̆̆ında tüm ifadeler katılım hemen hemen aynı olmakla beraber; "ihtiyacım olmasa bile bir ürünü promosyon olduğ için satın alırım", "aklımdaki marka yerine promosyonlu markayı almayı tercihe derim", "işletmelerin yapmış olduğu fiyat indirimleri satın alma kararımı etkiler"ve "promosyonlar yeni ürünleri denememi sağlar"ifadelerine katılım oranının yüksek olduğu görülmektedir. Dolayısıyla tüketiciler tüm satış geliştirme tekniklerinden eşit düzeyde etkilenmekte; ancak fiyat indirimlerinden daha fazla etkilenmektedir. Tüketiciler uygulanan satış geliştirme teknikleri sayesinde ihtiyaç olmasa bile bir ürünü satın alabilmekte, tercihlerini promosyonlu marka yönünde yapmakta ve yeni ürünleri deneyebilmektedir. Dolayısıyla ilk bölümde olduğu gibi tüketiciler "değer elde etmek için alışveriş"yapmaktadır.

Araştırmaya katılan ve hedonik tüketim sergileyen tüketicilerin satış geliştirme tekniklerinden etkilenmeleri korelasyon analizi ile test edilmiş ve hedonik tüketim davranışı sergileyen tüketicilerin satış geliştirme tekniklerinden etkilendiği ve satın alma kararlarını bu yönde verdikleri görülmüştür.Satın alma kararlarında öncelikle fiyata dikkat eden tüketiciler işletmelerin yapmış olduğu fiyat indirimlerinden etkilenmektedir. Bir diğer deyişle fiyat indirimleri fiyata dikkat eden tüketicileri etkilemektedir. Promosyonlu ürünleri tercih eden tüketiciler; böylece promosyonlar sayesinde yeni ürünleri denediği fikrine sahiptir.Promosyonlu ürünleri tercih eden tüketiciler; promosyonlar sayesinde kendini iyi hissetmektedir.Promosyonlu ürünleri tercih eden tüketiciler bu yüzden çevrelerindeki insanlar tarafindan takdir edildiklerini düşünmekte; aynı şekilde promosyonlu ürünleri tercih ettikleri için takdir edildiklerini düşünen tüketiciler promosyonlu ürünleri tercih etmektedir. Dolayısıyla promosyonlu ürünleri tercih etmekten dolayı takdir görmekten haz duymaktadırlar.Promosyonlu ürünleri tercih eden tüketiciler; aklındaki marka yerine promoyonlu ürünleri tercih etmektedir.Promosyonlu ürünleri tercih eden tüketiciler, ihtiyacı olmasa bile promosyon olduğu için ürün satın almaktadır.

Tüm bu bulgular ışı̆̆ında satış geliştirme teknikleri hedonik tüketim davranışı sergileyen tüketicilerin satın alma kararlarını etkilemektedir şeklinde yorumlanabilir.Tüm bu sonuçlar ışı̆̆ında satış geliştirme tekniklerinin hedonik tüketim üzerinde etkisi bulunmaktadır. Araştırmaya katılan tüketiciler hedonik tüketim davranışı sergilemekte en çok da değer elde etmek için alışevriş yapmaktadır ve satın alma kararları satış geliştirme tekniklerinden etkilenmektedir. Konu ile gelecek çalışmalarda kültürün hedonik tüketim üzerindeki etkisi araştırma konusu olabilir. Diğer yandan fiyat dışı satış geliştirme tekniklerinin de hedonik tüketiciler üzerinde etkisinin nasıl mümkün olacağı araştırma konusu olabilir.Fiyat dışı satış geliştirme tekniklerinin de hedonik tüketiciler üzerinde etkili olması için işletmeler daha farklı stratejiler izleyip, tüketicilerin dikkatini çekecek ve onları satın almaya yöneltecek şekilde fiyat dışı satış geliştirme tekniklerini daha cazip hale getirebilir.

\section{Kaynakça:-}

1. Ailiwadi, K.L. (2001). The Retail Power-Performance Conundrum: What Have We Learned. Journal of Retailing. 77(3):299-318.

2. Akarsu, B. (1998). Mutluluk Ahlakl: Ahlak Öğretiler-I. İstanbul: Kitabevi.

3. Akca, E.(2009). Hedonik Tüketim Davranışıını Belirleyen Demografik Faktörlerin Analizi. (Yayınlanmamış Yüksek Lisans Tezi). Kütahya: Dumlupınar Üniversitesi.

4. Akdoğan, G. (2007). Endüstriyel Pazarlarda Aracılara Uygulanan Satış Geliştirme Yöntemlerinin Satı̧̧la İlişkisi ve Bir Uygulama. (Yayınlanmamış Yüksek Lisans Tezi). İstanbul: Marmara Üniversitesi Sosyal Bilimler Enstitüsü.

5. Akın, F. (2009). Kooperatif Işsletmelerde Tutundurma Faaliyetlerinin Etkinliği Açısından Bütünleşik Pazarlama Iletiş̧imi ve Bir Uygulama. (Yayınlanmamış Yüksek Lisans Tezi). İstanbul: Marmara Üniversitesi Sosyal Bilimler Enstitüsü.

6. Altunışık R., Özdemir Ş. ve Torlak Ö. (2002). Modern Pazarlama. İstanbul: Değişim Yayınları. 
7. Antonides, G. ve Raaij, W. F. (1998). Consumer Behaviour: A European Perspective. New York: John Wiley ve Son.

8. Arnold, Mark J., Reynolds, Kristy E. (2003). Hedonic Shopping Motivations. Journal of Retailing. (79): 77-95.

9. Assael, H. (1993). Marketing Principles \&Strategy (Second Edition). Florida: The Dryden Press Harcourt Prace Jovanovich.

10. Aydın, S. (2009). Bireyci Toplumcu, İdalist-Relativist ve Materyalist Eğilimler İle Hedonik Allşveriş Arasındaki İlişkiler. (Yayınlanmamış Doktora Tezi). Afyon Kocatepe Üniversitesi Sosyal Bilimler Enstitüsü.

11. Babin, B.J., Darden, W. R. ve Griffin, M. (1994). Workand/or Fun: Measuring Hedonic and Utilitarian Shupping Value. Journal of Consumer Research. 20(4): 646.

12. Baudrillard, J. (2004). Tüketim Toplumu. Çev. H. Deliceçaylı. İstanbul: SarmalYayınları.

13. Baker, M. J. (1993). Marketing: An Introductory Tex. Macmillan Press.

14. Bridges, E., Briesch, R. A. ve Yim, C.K. (Bennet) (2006). Effects of Prior Brand Usage and Promotion on Consumer Promotional Response. Journal of Retailing. 82(4):1

15. Bulut, Y. (2007). Tüketicilerin Satış Geliştirme Faaliyetlerine Illişkin Tutum Ve Yarar Algılamaları. (Yayınlanmamış Doktora Tezi). İstanbul: Marmara Üniversitesi

16. Campell, C. (1987). The Romantic Ethic and the Spirit of Modern Consumerism. New York: Blacwell Pub.

17. Carman, J.M. (1978).Values and Consumption Patterns: A Closed Loop. Advanced in Consumer Research. http://www.acrwebsite.org/search/viewconferenceproceedings.aspx ?Id=9455. (12.06.2015).

18. Cemalcılar, İ. (1988). Pazarlama: Kavramlar ve İlkeler. İstanbul: Beta Yayınevi.

19. Chandon, P. ve Vansink, B. (2000). A Benefit Congruency Framework of Sales Promotion LAURENT Gilles Effectiveness. Journal of Marketing.64(1): 1.

20. Chen, S.F.S., Monroe K.B. ve Lou Y.C. (1998). "The Effects of Framing Price PromotionMessages on Consumers Perceptions And Purchase Intentions". Journal of Retailing.74(3):353-372.

21. DeLozier, M. W. (1976). The Marketing Communication Process. Newyork: Mc. Graw-Hill Book Co.

22. Dhar, R. ve Wertenbroch K. (2000). Consumer Choice Between Hedonic and Utilitarian Goods. Journal of Marketing Research. 37(1): 60.

23. Dikici, F.H. (2001). Süpermarketlerde Satıs Tutundurma Faaliyetleri ve Isparta Uygulaması. (Yayınlanmamış Yüksek Lisans Tezi). Isparta: Süleyman Demirel Üniversitesi Sosyal Bilimler Enstitüsü.

24. Engel, J. F., Warshaw, M.R., Kinnear, T.C. ve Reece, B. B. (2000). Promotional Strategy: An Integrated Marketing Communication Approach. Cincinnati, OH: Pinnaflex Educational Resources.

25. Flocker, M. (2004). The Hedonism Handbook: Mastering the Lost Arts of Leisure and Pleasure. Cambridge: Da Capo Press

26. Fromm, E. (1991). Sahip Olmak ya da Olmamak. Çev. Aydın Arıtan. İstanbul: Arıtan Yayınevi.

27. Fromm, E. (1995). Erdem ve Mutluluk. Çev. Ayda Yörükan. İstanbul: Türkiye İş Bankası Kültür Yayınları.

28. Gedenk, K.ve Neslin, S. A. (1999). "The Role Of Retail Promotion in Determining Future Brand Loyalty: Its Effect On Purchase Event Feedback”. Journal of Retailing. 75(4):433-459.

29. Gülçubuk, A. (2007). Tüketicilere Yönelik Satış Geliştirmenin Artan Önemi, Uygulanabilirliği Ve İzlenecek Stratejilerin İşletmeler Açısından Değerlendirilmesi. Ege Akademik Bakış. 7(1): 57-77.

30. Gürcan, Ş. (2007). Sponsorluk Yönetiminin Tutundurma Etkisi Ve Denizli İli Tekstil Sektöründe Bir Uygulama. (Yayınlanmamış Yüksek Lisans Tezi). Ankara: Gazi Üniversitesi Sosyal Bilimler Enstitüsü.

31. Hançerlioğlu, O.(2004). Felsefe Sözlüğü.İstanbul: Remzi Kİtabevi.

32. Hardesty, D. M. ve Bearden W.O. (2003). Consumer Evaluations of Different Promotion Types and Price Presentations: The Moderating Role of Promotional Benefit Level. Journal of Retailing.79(1): 17-25.

33. Hiraoka, C. (2009). Technology Acceptance of Connected Services in the Automotive Industry. Wiesbaden: Gabler.

34. Hirschman, E.C., ve Holbrook, M. B. (1982). Hedonic Consuption: Emerging Consepts. Journal of Marketing. 46(3): 92-101.

35. Holbrook, M.B. (1996). Romanticism: "Introspection and the Roots of Experiential Consumption: Morris the Epicurean". Consumption and Marketing Macro Dimensions (der. Russell W. Belk, Nikhilesh Dholakia, A. Venkadesh). Cincinat: South-Western College Pub.

36. Hopkinson, G. C. ve Pujari, D. (1999). A Factor Analytic Study of The Sources of Meaning in Hedonic Consumption. European Journal of Marketing. 33(3/4): 273-290.

37. ldoceonline. (2014). Pleasure. http://www.ldoceonline.com/dictionary/pleasure. (02.12.2014)

38. Kara, M. ve Kara, D. (2013). Satı̧̧ Geliştirme Yöntemlerinin Satın Alma Kararına Etkisi: Hizmet Sektöründe Bir Uygulama. Adlyaman Üniversitesi Sosyal Bilimler Enstitüsü Dergisi. 6(12): 149-190. 
39. Karabulut, M. (1987). Değişen Hayat Tarzı ve Hedonizm. Pazarlama Dünyası.1(1): 9.

40. Kizza, J.M.(2010). Ethical and Social Issues in the Information Age. New York: Springer.

41. Koldaş, A.N. (2006). Ticari Fuarların Satış Geliştirme Etkisi ve Bir Uygulama. (Yayınlanmamış Yüksek Lisans Tezi). Ankara: Gazi Üniversitesi Sosyal Bilimler Enstitüsü.

42. Kop, E.A. (2008). Satın Alma Davranışında Hedonik ve Faydacı Tüketimin Ölçülmesi ile İlgili Bir Uygulama. (Yayınlanmamış Yüksek Lisans Tezi). İstanbul: Marmara Üniversitesi Sosyal Bilimler Enstitüsü.

43. Kotler, P. ve Armstrong, G. (1993). Marketing and Introduction. London: Prentice Hall.

44. Kotler, P. ve Armstrong, G. (2008). Principles of Marketing. London: Pearson Education.

45. Kotler, P. (2005). A'dan Z'ye Pazarlama. Çev. Aslı Kalem Bakkal. İstanbul: Mediacat Yayınları.

46. Levy, M. ve Barton, A. W. (1995). Retailing Marketing. Irwin: Mc Graw Hill.

47. Odabaşı, Y. (2006). Tüketim Kültürü. İstanbul: Sistem Yayıncılık.

48. Odabaş1, Y. ve Oyman, M.(2002). Pazarlama İletişimi Yönetimi. İstanbul: Kapital Medya Hizmetleri A.Ş.

49. Okado, E.M. (2005). Justification Effects on Consumer Choice of Hedonic and Utilitarian Goods. Journal of Marketing Research. 22(2): 43-53.

50. O’Shaughnessy, John, O’Shaughnessy ve Nicolas J. (2002). Marketing the Consumer Society and Hedonism. European Journal of Marketing. 36(5/6): 524-547.

51. Özdemir, Ş. (2007). Hazcı (Hedonik)Tüketim Davranışlarında Televizyonun Rolü: SDÜ Öğrencileri Üzerine Bir Araştırma. (Yayınlanmamış Yüksek Lisans Tezi). Isparta: Süleyman Demirel Üniversitesi Sosyal Bilimler Enstitüsü.

52. Öztürk, A.S. (1993). Tüketicilere Yönelik Satış Tutundurma Faaliyetleri ve Planlama Süreci: Tüketim Malları Üreten İşletmelerde Bir Araştırma. (Yayınlanmamış Doktora Tezi). Eskişehir: Anadolu Üniversitesi Sosyal Bilimler Enstitüsü.

53. Penpece, D. (2006). Tüketici Davranışlarını Belirleyen Etmenler: Kültürün Tüketici Davranışları Üzerindeki Etkisi. (Yayınlanmamış Yüksek Lisans Tezi). Kahramanmaraş: Kahramanmaraş Sütçü İmam Üniversitesi.

54. Pöyry, E. (2012). Hedonic and Utilitarian Search for Electronic Word-of-Mouth. System Science (HICSS); 2012 45th Hawaii International Conference. 1797-1806.

55. Rosinsky, N. M. (2004). Spending Money. Minneapolis: Compass Point Books.

56. Sethuraman, Raj, Tellis, Gerard J. (2002). Does Manufacturer Advertising Suppress or Stimulate Retail Price Promotions? Analytical Model and Empirical Analysis. Journal of Retailing. 78 (1) :253-263.

57. Sigué, S. P. (2008). Consumer and Retailer Promotions. Journal of Retailing. 84(4):449-460.

58. Slater, J. (2001). Is Couponing an Effective Promotional Strategy? An Examination of the Procter\&Gamble Zero-Coupon Test. Journal of Marketing Communications.7(1): 3-9.

59. Solomon, M. R. (2007). Consumer Behaviour: Buying, Having and Being. (Third Edition). USA: Pearson Prentice Hall.

60. Srinivasan, S., Pauwels, K., Hanssens D. M. ve Dekimpe, M.G. (2002). Do Promotions Benefit Manufacturers Retailers Or Both?.Erim Report Series Research in Management. 1(1): 2

61. Terpstra, V. ve Sarathy, R. (2000). International Marketing (8. Edition). USA: Harcourt College Publishing.

62. Tyagi, R. K. (1999). A Characterization of Retailer Response to Manufacturer Trade Deals. Journal of Marketing Research. 36(4):510-516.

63. Ülker, D. (2009). Yeni Ürünlerde Uygulanan Tutundurma Stratejileri ve Bir Uygulama. (Yayınlanmamış Yüksek Lisans Tezi). İzmir: Dokuz Eylül Üniversitesi Sosyal Bilimler Enstitüsü.

64. Ünal, S. ve Ceylan, C. (2008). Tüketicileri Hedonik Alışverişe Yönelten Nedenler: İstanbul ve Erzurum İllerindearşılaştırmalı Bir Araştırma. Atatürk Üniversitesi: İktisadi ve İdari Bilimler Dergisi. 22(2):265-283.

65. Wansink, B. (1996). Can Package Size Accelerate Usage Volume. Journal of Marketing. 60 (3):1-14.

66. Westbrook, R. A. ve Black, W. C. (March 1985). A Motivation-Based Shopper Typlogy. Journal of Retailing. 61(1): 78-103.

67. White, N.P. (2006). A Brief History of Happiness. Oxford: Blackwell Publishing.

68. Yanıklar, C. (2006). Tüketimin Sosyolojisi. İstanbul: Birey Yayınc1lık.

69. Yi, Gao, Ying, Liang Yun (2009). Business to Consumer Web-Site Under The Financial Crisis. (Yayınlanmamış Yüksek Lisans Tezi). Halmstad: University of Halmstad.

70. Yolal, M. (1998). Konaklama İşletmelerinde Önbüronun Satış Geliştirme ve Gelir Artırmadaki İşlevinin Yapısal Analizi ve Bir Alan Araştırması. (Yayınlanmamış Yayınlanmamış Yüksek Lisans Tezi). Eskişehir: Anadolu Üniversitesi Sosyal Bilimler Enstitüsü.

71. Zaichkowsky, J. L. (1985). "Measuring the Involvement Construct". Journal of Consumer Research. 12(3): 341-352. 